\title{
INFLUENCES OF INTERCROPPING TWO LEGUME CROPS AND MINERAL NITROGEN FERTILZER ON WHEAT YIELD AND MICRO - ORGANISMS ACTIVITY IN THE RHIZOPSPHERE SOIL.
}

(Received: 25.12.2016)

\author{
By \\ N. M.A. Eissa , B. R.A. Rashwan* and Sh. H.F. Abozaed** \\ Crop Intensification Research Department, Field Crops Research Institute, \\ * Plant Nutrition Departments, Soil, and **Microbiology Departments, Soil, Water and \\ Environment Research Institute, Agricultural Research Center, Giza,Egypt.
}

\begin{abstract}
Two field trials were carried out at Mallawi Agric. Res. Sta. (Middle Egypt) during 2013/2014 and 2014/2015 seasons to evaluate the effect of different intercropping patterns of two legume crops with wheat under three mineral nitrogen $(\mathrm{N})$ fertilizer levels on soil bacterial activity, yields of intercropped crops and its quality. A split plot design with three replications was used. Main plots were devoted for $\mathrm{N}$ fertilizer levels $\left(60,75\right.$ and $\left.90 \mathrm{~kg} \mathrm{~N}^{-1}\right)$. The intercropping patterns $(100 \%$ wheat $+20 \%$ faba bean, $100 \%$ wheat $+30 \%$ faba bean, $100 \%$ wheat $+40 \%$ faba bean, $100 \%$ wheat + $20 \%$ fahl berseem, $100 \%$ wheat $+30 \%$ fahl berseem and $100 \%$ wheat $+40 \%$ fahl berseem) were allocated in sub - plots, in addition to sole cultures of wheat, fahl berseem and faba bean. Available soil content of NPK and organic matter, seed yield and its qualities of legume crops except fahl berseem were significantly increased by $\mathrm{N}$ levels application, intercropping patterns, and their interactions. The highest values of the studied traits were obtained with $90 \mathrm{~kg} \mathrm{~N}^{-1} \mathrm{fed}^{-1} \times 100 \%$ wheat $+40 \%$ faba bean compared to the other treatments. Biological properties and wheat traits were significantly affected by mineral $\mathrm{N}$ fertilizer levels, intercropping patterns and their interaction. Increasing $\mathrm{N}$ fertilizer level from 60 to $75 \mathrm{~kg} \mathrm{~N}^{-1} \mathrm{~d}^{-1}$ increased all the previous traits, $(\mathrm{P} \leq 0.05)$. Meanwhile the least values of the biological soil properties and wheat traits, except spike length and 1000 - kernel weight were obtained by increasing $\mathrm{N}$ fertilizer level to $90 \mathrm{~kg} \mathrm{~N}^{-1} \mathrm{~d}^{-1}$ Land equivalent ratio values were greater than one, which indicate increasing the land productivity per unit area. The highest values were obtained by (1.33) under intercropping pattern $100 \%$ wheat $+20.0 \%$ faba bean that received $75 \mathrm{~kg} \mathrm{~N} \mathrm{fed}^{-1}$. Wheat crop was more competitive than fahl berseem or faba bean indicating the dominance of wheat on fahl berseem or faba bean. The highest net return was achieved by intercropping patterns $100 \%$ wheat $+20 \%$ faba bean or $100 \%$ wheat $+20 \%$ fahl berseem that received $75 \mathrm{~kg} \mathrm{~N}$ fed $^{-1}$ increased net return of farmers by L.E. 2553 and 2488 per fad, respectively, over those of sole wheat. Application of $75 \mathrm{~kg} \mathrm{~N} \mathrm{fed}^{-1}$ with the lowest number of plants of intercropped legumes achieved high quality of all the tested crops. Simple correlation was also studied the relationships between soil nitrogen and soil microbial content traits as well as, between spikes $\mathrm{m}^{-2}$ and its components traits
\end{abstract}

Key words: Intercropping, Wheat, Fahl berseem, Faba bean, Biological, Mineral N fertilizer levels, Soil content, Simple correlation, Quality, Net return.

\section{INTRODUCTION}

In Egypt, increasing wheat ( Triticum

Aestivum L.) production is a national target to fill the gap between wheat consumption and production. Great attention and efforts have been paid by the Egyptian government and agricultural scientists to narrow wheat security gap. The total cultivated area of wheat, barseem and faba bean have reached about 3.468, 1.297 and 89.710 thousand faddans, respectively (Bulletin of Statistical Cost Production and Net Return, 2015).

In cereal - legume rotation or intercropping systems, the cereal benefits from the nitrogen fixed by the legume and the decomposition of nutrient-vies biomass, root and nodules of legume which help to increase soil organic matter as well as reduces weeds competition. 
Gregorich et al. (2001), Chen et al. (2004), and Eskandari \& Ghanbari (2010) showed that plant height, spike length, no. of grains/spike, weight of 1000 grains and straw yield $\mathrm{fed}^{-1}$ of wheat increased by intercropping with faba bean or white clover compared to wheat monoculture. El Naggar et al. (1991) found that intercropping systems compared with the sole crop decreased legume crop yields. Intercropping systems had a significant effect on environment consumption, where intercropping systems had more light interception and water, and nutrient uptake compared to sole crops, suggesting the complementarity effect of intercropping components in resources consumption. The ability of wheat and bean was different in intercropping systems in absorbing nutrients because of their differences in root morphology and action exchange capacity (Eskandari, 2011). This may be due to some of the potential benefits for intercropping systems such as high productivity and profitability. Yildirim and Guvence, 2005, Sheha et al. (2015) showed that application of mineral $\mathrm{N}$ fertilizer doses increased grain yield of intercropped wheat, but had non-significant effect on intercropped green pod yield of pea. Land equivalent ratio (LER) for intercrops was much greater than 1.00, indicating that land requirements of intercropping systems was less than sole wheat. As a result of intercropping; yield, $\mathrm{N}$ uptake and net returns were improved in intercropped wheat with pea (Abdel-Wahab and Elmanzalawy, 2016). The results that land equivalent ratio and land equivalent coefficient values for intercrops were much greater than 1.00 and 0.25 , respectively, indicating less land requirements of intercropping systems than sole wheat. The results of Basma et al. (2016) showed that with increasing the level of mineral nitrogen fertilization from $0,50,75$ and $100 \% \mathrm{~N} \mathrm{fed}^{-1}$ the highest significant values of all studied parameters (1000 grain weight, grain yield, straw yield, protein percentage in grains, $\mathrm{N}$ content in grain and straw, nitrogen uptake by grain, nitrogen uptake by straw and total nitrogen uptake by grain and straw) were achieved from application of $75 \mathrm{~kg} \mathrm{~N} \mathrm{fed}^{-1}$. Several studies have shown that through biological nitrogen fixation, which is enhanced by inoculation to the compatible host legume leave residual nitrogen in the soil which add organic matter and also becomes a source of cheap nutrients for the next cropping season to cereal crops and other legumes (Zahran,1999).
Biological nitrogen fixation is therefore considered to have ecological and economic benefits (Ndakidemi et al., 2006). The ability to secrete a vast array of compounds into the rhizosphere is one of the most remarkable metabolic features of plant roots, with nearly 5\% to $21 \%$ of all photo-synthetically fixed carbon being transferred to the rhizosphere through root exudates (Marschner, 2001). There were different studies on intercropping either clover or faba bean with wheat over a long period (Abou-Keriasha et al., 2013; Mohammed Wafaa, 2014 ; Bargaz et al., 2015 and Abdel-Wahab and El Manzlawy, 2016). Generally, it is known that any plant obtain mineral nutrients through root uptake from the soil solution. So, it is expected that the interaction in the rhizosphere of those intercrop mineral $\mathrm{N}$ fertilizer through activity of soil microorganisms where soil bacterial community composition is altered in response to nitrogen addition (Jian-Gang et al., 2016). Therefore, the main objective of the present research was to evaluate the effect of different intercropping patterns of Egyptian clover or faba bean with wheat under three mineral $\mathrm{N}$ fertilizer levels on soil bacterial activity yields and quality of the intercropped field crops.

\section{MATERIALS AND METHODS}

Two field trials were carried out at Mallawi Agric. Exp. Res. Sta., A.R.C., El-Mania Governorate, Egypt, during 2013/2014 and 2014/2015 seasons. The aim of these experiments was to study the effect of different intercropping patterns of fahl berseem or faba bean with wheat under three mineral nitrogen (N) fertilizer levels on bacterial soil activity, and yields and qualities of the intercropped field crops. Maize was the preceding summer crop in both seasons. A split plot design in three replications was used, where the main plots were devoted to three nitrogen levels $(60,75$ and 90 $\left.\mathrm{kg} \mathrm{N} \mathrm{fed}{ }^{-1}\right)$. Sub-plots were devoted to six intercropping patterns of faba bean or fahl berseem with wheat. These intercropped patterns could be illustrated as follows:

$\mathrm{B}_{1}$ : Wheat grains $\left(60 \mathrm{~kg} \mathrm{fed}^{-1}\right)$ were drilled in 6 rows in the middle of the bed $(120 \mathrm{~cm}$ width) and faba bean seeds (6 $\left.\mathrm{kg} \mathrm{fed}^{-1}\right)$ were sown on both sides of the bed then thinned to one plant /hill distanced at $25 \mathrm{~cm}$ between plants $(100 \%$ wheat $+20.0 \%$ faba

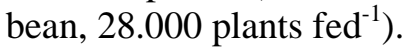


$\mathrm{B}_{2}$ : Wheat grains $\left(60 \mathrm{~kg} \mathrm{fed}^{-1}\right)$ were drilled in 6 rows in the middle of the bed $(120 \mathrm{~cm}$ width) and faba bean seeds $\left(9 \mathrm{~kg} \mathrm{fed}^{-1}\right)$ were sown on both sides of the bed then thinned to one plant /hill only on one side and faba bean plants of the other side were thinned to two plants/hill distanced at 25 $\mathrm{cm}$ between plants $(100 \%$ wheat $+30.0 \%$ faba bean, 42.000 plants fed $\left.^{-1}\right)$.

$\mathrm{B}_{3}$ : Wheat grains $\left(60 \mathrm{~kg} \mathrm{fed}^{-1}\right)$ were drilled in 6 rows in the middle of the bed $(120 \mathrm{~cm}$ width) and faba bean seeds (12 kg fed $\left.{ }^{-1}\right)$ were sown on both sides of the bed then thinned to two plants/hill distanced at 25 $\mathrm{cm}$ between plants. (100\% wheat $+40 \%$ faba bean, 58.000 plants fed $\left.^{-1}\right)$.

$\mathrm{B}_{4}$ : Wheat grains $\left(60 \mathrm{~kg} \mathrm{fed}^{-1}\right)$ were drilled in 6 rows in the middle of the bed $(120 \mathrm{~cm}$ width) and fahl berseem seeds $\left(3 \mathrm{~kg} \mathrm{fed}^{-1}\right)$ were broadcasted on bottom of the bed $(100 \%$ wheat $+20 \%$ fahl berseem $)$.

$\mathrm{B}_{5}$ : Wheat grains $\left(60 \mathrm{~kg} \mathrm{fed}^{-1}\right)$ were drilled in 6 rows in the middle of the bed $(120 \mathrm{~cm}$ width) and fahl berseem seeds $\left(4.5 \mathrm{~kg} \mathrm{fed}^{-1}\right)$ were broadcasted on bottom of the bed $(100 \%$ wheat $+30 \%$ fahl berseem).

$B_{6}$ : Wheat grains $\left(60 \mathrm{~kg} \mathrm{fed}^{-1}\right)$ were drilled in 6 rows in the middle of the bed $(120 \mathrm{~cm}$ width) and fahl berseem seeds $\left(6 \mathrm{~kg} \mathrm{fed}^{-1}\right)$ were broadcasted on bottom of the bed ( $100 \%$ wheat $+40 \%$ fahl berseem) .

Subplot area was $24 \mathrm{~m}^{2}(1 / 175 \mathrm{fed})$, the wheat bed unit measured $5 \mathrm{~m}$ in width and $4 \mathrm{~m}$ in length. Bread wheat (cv. Giza 168.) was sown at a seed rate of $60 \mathrm{~kg} \mathrm{fed}^{-1}$ on the $10^{\text {th }}$ and $15^{\text {th }}$ of November at 2013 and 2014 seasons. Faba bean (cv. Giza 843) and fahl berseem (cv. Gemmiza 1 veriety) were used.Wheat grains (60 $\left.\mathrm{kg} \mathrm{fed}^{-1}\right)$, faba bean seeds $\left(30 \mathrm{~kg} \mathrm{fed}^{-1}\right)$ and fahl berseem seeds $\left(15 \mathrm{~kg} \mathrm{fed}^{-1}\right)$ were grown solid to compare. Water was supplied as furrow irrigation. $\mathrm{N}$ fertilizer rates in form of ammonium nitrate $(33.5 \% \mathrm{~N})$ were applied in two equal doses before the first and the second irrigation. Calcium super phosphate $(15.5 \%$ $\left.\mathrm{P}_{2} \mathrm{O}_{5}\right)$ at the rate of $150 \mathrm{~kg} \mathrm{fed}^{-1}$ was side-dressed after ridging and potassium sulfate $(48.0 \%$ $\mathrm{K}_{2} \mathrm{O}$ ) at the rate of $24 \mathrm{~kg} \mathrm{fed}^{-1}$ was side-dressed before the second irrigation according to the treatments rate. Table (1) shows some physical and chemical properties of the experimental soil before sowing.

\subsection{Microbiological determination}

In vivo studies of both experiments, the total count of bacteria, Azotobacter, Azospirilum and phosphate dissolving bacteria in rhizosphere per gram soil at 45 days after sowing were determined using dilution frequency method (Haskine, 1934). Numbers of phosphate dissolving bacteria were determined as described by Abdel-Moniem et al. (1988). Numbers of bacterial total count were determined as described by Allen (1959). Some physical and chemical properties of the surface layer $(0-30$ $\mathrm{cm}$ ) of the soil at the start of each growing season, samples of soil surface were collected dried, sieved prior to laboratory analysis according to Piper (1950) and Black, (1965). Soil $\mathrm{pH}$ was determined in the suspension of soil sample (1 soil: 2.5 water v.:v.) according to Richards, (1954). The electrical conductivity (EC $\mathrm{dsm}^{-1}$ ) was measured by an electrical conductivity meter in the soil extract (1 soil: 5 water v.:v.) according to Richards (1954). These analyses were done by Environment, Water and Soil Research Institute, A.R.C., Egypt.

\subsection{Data recorded}

\subsubsection{Yield and Its Attributes}

On $26^{\text {th }}$ and $29^{\text {th }}$ April, 2014 and 2015 seasons, faba bean plants were harvested, and on $20^{\text {th }}$ and $25^{\text {th }}$ May 2014 and 2015 seasons, wheat and fahl berseem plants were together harvested. The following traits were measured on ten random plants from each plot:

2.2.1.1. Wheat: Plant height, spike length, number of spikes $\mathrm{m}^{-2}$,number of kernels spike ${ }^{-1}$ and 1000 - kernel weight area by harvesting all plants of each sub plot and expressed as ton $\mathrm{fed}^{-1}$. 2.2.1.2. Barseem: Seed yield was recorded on the basis of experimental sub-plot area by harvesting all the plants of each sub plot and expressed as $\mathrm{kg} \mathrm{fed}^{-1}$.

2.2.1.3. Faba bean: Seed yield was recorded on the basis of experimental sub-plot area by harvesting all the plants of each sub plot and expressed as $\mathrm{kg} \mathrm{fed}^{-1}$.

\subsubsection{Chemical composition of yields}

At harvest, grain and straw samples were dried in a forced oven at $70{ }^{\circ} \mathrm{C}$ till constant weight; ground to a fine powder and sub sample of $0.2 \mathrm{~g}$ was wet digested using sulphuricperchloric acid mixture (1:1) as described by A.O.A.C., (2000) to determine the total $\mathrm{N}$ in the acidic extract as follows:

2.2.2.1. Total $\mathrm{N}(\%)$ was determined by Kjeldahl method as according to Jackson (1967).

2.2.2.2. Crude protein (\%) in wheat grains, faba bean seeds and barseem seeds were calculated 
Table (1): Physical and chemical properties of the experimental soil (before sowing).

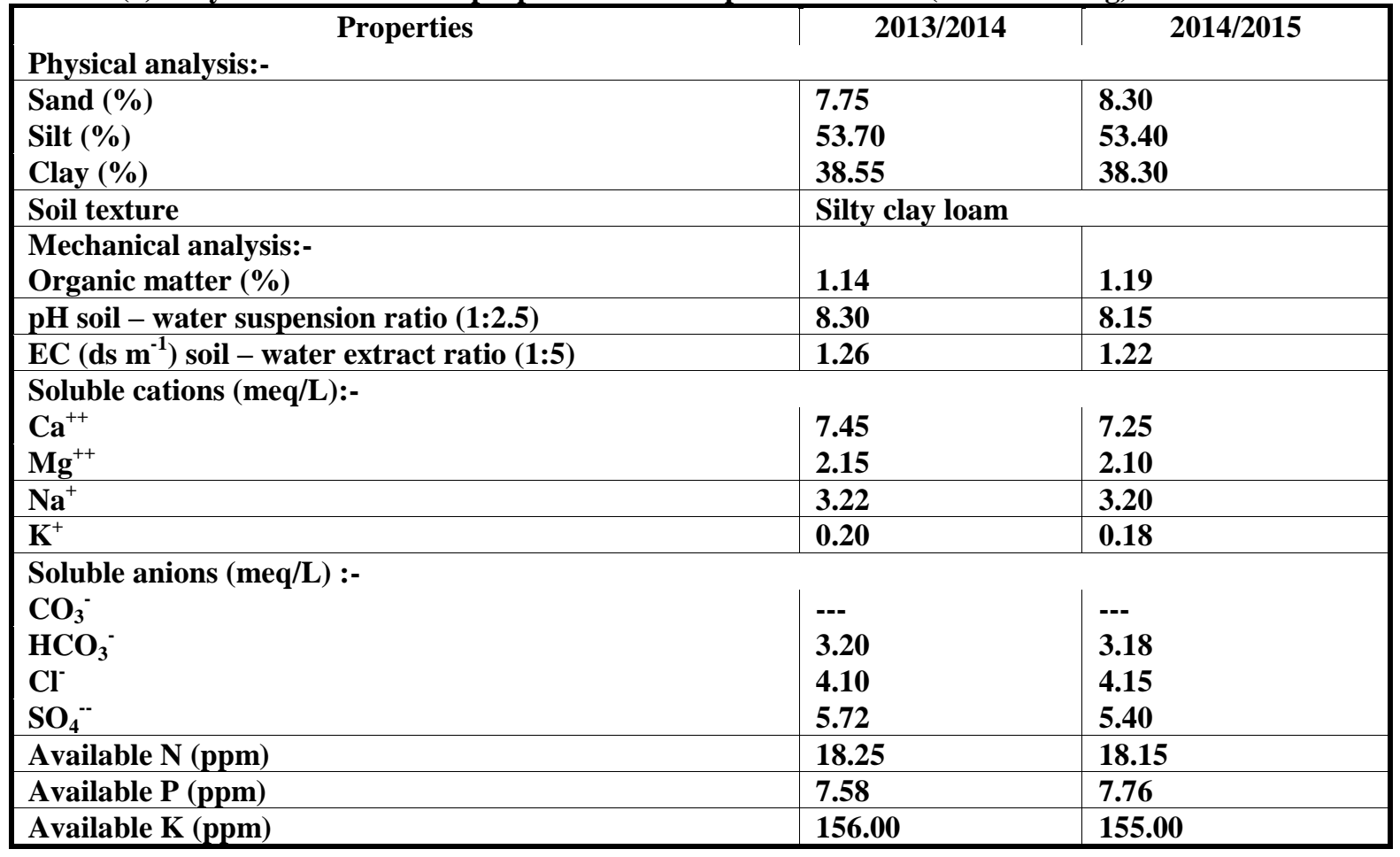

by multiplying $\mathrm{N} \%$ by 5.7 for wheat grains, 6.25 for faba bean and barseem seeds according to Tripath et al. (1971) and Sadasivam and Manickam (1997).

2.3. Correlation matrix: The coefficients of correlation between all pairs of the studied traits were computed as suggested by Snedecor and Cochran, (1989).

\subsection{Competitive relationships}

2.4.1. Land equivalent ratio (LER): was estimated according to Mead and Willey (1980) as follows: -The values of LERs were estimated by using data of sole crops. LER of more than 1.00 indicates yield advantage, equal to 1.00 indicates no gain or no loss and less than 1.00 indicates yield loss (Vendemeer, 1989). It can be used for both replacement and additives series of intercropping.

$$
\mathrm{LER}=\left(\mathrm{Y}_{\mathrm{ab}} / \mathrm{Y}_{\mathrm{aa}}\right)+\left(\mathrm{Y}_{\mathrm{ba}} / \mathrm{Y}_{\mathrm{bb}}\right)
$$

Where $Y_{a a}$ and $Y_{b b}$ is pure stand of crops $a$ and $b$, Yab and Yba were intercropped crops $a$ and $b$.

2.4.2. Competitive ratio (CR): It was measured as proposed by Willey and Rao, (1980). It gives the exact degree of competition by indicating the times in which one crop is more competitive than the other. Competition ratio $(\mathrm{CR})$ is calculated according to the following equation:

$\mathrm{Ra}=\left(\mathrm{L}_{\mathrm{a}} / \mathrm{L}_{\mathrm{b}}\right) \times\left(\mathrm{Z}_{\mathrm{ba}} / \mathrm{Z}_{\mathrm{ab}}\right)$

$\mathrm{R}_{\mathrm{b}}=\left(\mathrm{L}_{\mathrm{b}} / \mathrm{L}_{\mathrm{a}}\right) \times\left(\mathrm{Z}_{\mathrm{ab}} / \mathrm{Z}_{\mathrm{ba}}\right)$

Where $\mathrm{Ra}$ and $\mathrm{R}_{\mathrm{b}}=$ the competitive ratio of crops $\mathrm{a}$ and $\mathrm{b}$.
$\mathrm{L}_{\mathrm{a}}=\mathrm{LER}$ of crop a $\mathrm{L}_{\mathrm{b}}=\mathrm{LER}$ of crop $_{\mathrm{b}}$

$\mathrm{Z}_{\mathrm{ab}}=$ the respective proportion of crop $\mathrm{a}$ in the intercropping system

$\mathrm{Z}_{\mathrm{ba}}=$ the respective proportion of crop $\mathrm{b}$ in the intercropping system

2.4.3. Farmer's benefit: It was calculated by determining the total costs and net return of intercropping culture as compared to recommended sole culture as follows:

2.4.3.1. Total return of intercropping cultures $=$ Price of wheat $\times$ yield + price of barseem or faba bean $\times$ yield (L.E.), to calculate the total return, the average market price $2800 \mathrm{~L}$.E. / ton wheat, 7.400 L.E./ kg faba been 500 L.E/ ton straw yield and 20.00 L.E./ $\mathrm{kg}$ seed for barseem fahl prices were used by Bulletin of Statistical Cost Production and Net Return, (2015).

2.4.3.2. Net return $=$ Total return - (fixed costs of wheat + variable costs of barseem or faba bean according to plant density and $\mathrm{N}$ fertilizer type).

2.5. Statistical Analysis: All data of the two seasons were statistically analyzed according to Snedecor and Cochran (1989) using MSTAT software Computer V4 (1980). L.S.D. test at $5 \%$ level was used to compare between treatments.

\section{RESULTS AND DISCUSSIONS}

- 3.1. Soil chemical analyses

\subsubsection{Mineral $\mathbf{N}$ fertilizer levels}

Data in Table (2) show that mineral $\mathrm{N}$ fertilizer levels had significant effects on soil 
Table (2): Effect of $\mathrm{N}$ fertilizer levels, intercropping patterns and their interactions on some soil chemical properties combined data across 2013/2014 and 2014/2015.

\begin{tabular}{|c|c|c|c|c|c|}
\hline \multicolumn{2}{|c|}{ Traits } & $\mathbf{N}(\mathbf{p p m})$ & $\mathbf{P}(\mathbf{p p m})$ & K (ppm) & O. M. \% \\
\hline \multicolumn{6}{|c|}{ Nitrogen fertilizer levels } \\
\hline \multicolumn{2}{|l|}{$60 \mathrm{~kg} \mathrm{fed}^{-1}\left(\mathbf{F}_{1}\right)$} & 19.133 & 7.923 & 157.864 & 1.451 \\
\hline \multicolumn{2}{|l|}{$75 \mathrm{~kg} \mathrm{fed}^{-1}\left(\mathbf{F}_{2}\right)$} & 19.170 & 7.975 & 160.183 & 1.481 \\
\hline \multicolumn{2}{|l|}{$90 \mathrm{~kg} \mathrm{fed}^{-1}\left(\mathbf{F}_{\mathbf{3}}\right)$} & 19.284 & 8.0102 & 161.680 & 1.506 \\
\hline \multicolumn{2}{|l|}{ L.S.D. 0.05} & 0.008 & 0.011 & 0.200 & 0.015 \\
\hline \multicolumn{6}{|l|}{ Intercropping } \\
\hline \multicolumn{2}{|c|}{$100 \%$ wheat $+20 \%$ faba bean $\left(\mathbf{B}_{1}\right)$} & 19.208 & 7.941 & 159.683 & 1.446 \\
\hline \multirow{2}{*}{\multicolumn{2}{|c|}{$\begin{array}{l}100 \% \text { wheat }+30 \% \text { faba bean }\left(\mathbf{B}_{2}\right) \\
100 \% \text { wheat }+40 \% \text { faba bean }\left(\mathbf{B}_{3}\right)\end{array}$}} & 19.218 & 8.024 & 160.291 & 1.465 \\
\hline & & 19.226 & 8.084 & 160.719 & 1.524 \\
\hline \multicolumn{2}{|c|}{$100 \%$ wheat $+20 \%$ fahl berseem $\left(\mathbf{B}_{4}\right)$} & 19.156 & 7.954 & 158.816 & 1.530 \\
\hline \multicolumn{2}{|c|}{$100 \%$ wheat $+30 \%$ fahl barseem $\left(\mathbf{B}_{5}\right)$} & 19.182 & 7.988 & 158.932 & 1.468 \\
\hline \multicolumn{2}{|c|}{$100 \%$ wheat $+40 \%$ fahl berseem $\left(\mathbf{B}_{6}\right)$} & 19.182 & 8.023 & 159.455 & 1.448 \\
\hline \multicolumn{2}{|l|}{ L.S.D. 0.05} & 0.010 & 0.039 & 0.184 & 0.020 \\
\hline \multicolumn{6}{|l|}{ Interaction } \\
\hline \multirow[t]{6}{*}{$60 \mathrm{~kg} \mathrm{fed}^{-1}\left(\mathbf{F}_{1}\right)$} & $\mathbf{B}_{1}$ & 19.126 & 7.782 & 157.940 & 1.385 \\
\hline & $\mathbf{B}_{2}$ & 19.138 & 7.994 & 158.780 & 1.455 \\
\hline & $\mathbf{B}_{3}$ & 19.148 & 8.084 & 159.341 & 1.488 \\
\hline & $\mathbf{B}_{4}$ & 19.118 & 7.845 & 156.786 & 1.403 \\
\hline & $\mathbf{B}_{5}$ & 19.127 & 7.893 & 157.025 & 1.438 \\
\hline & $\mathbf{B}_{6}$ & 19.139 & 7.929 & 157.644 & 1.590 \\
\hline \multirow[t]{6}{*}{$75 \mathrm{~kg} \mathrm{fed}^{-1}\left(\mathbf{F}_{2}\right)$} & $\mathbf{B}_{1}$ & 19.178 & 7.890 & 159.775 & 1.407 \\
\hline & $\mathbf{B}_{2}$ & 19.189 & 7.924 & 159.900 & 1.463 \\
\hline & $\mathbf{B}_{3}$ & 19.190 & 7.986 & 159.947 & 1.483 \\
\hline & $\mathbf{B}_{4}$ & 19.130 & 8.000 & 158.783 & 1.390 \\
\hline & $\mathbf{B}_{5}$ & 19.159 & 8.034 & 158.787 & 1.508 \\
\hline & $B_{6}$ & 19.169 & 8.046 & 158.904 & 1.598 \\
\hline \multirow[t]{6}{*}{$90 \mathrm{~kg} \mathrm{fed}^{-1}\left(\mathbf{F}_{\mathbf{3}}\right)$} & $\mathbf{B}_{1}$ & 19.321 & 8.150 & 161.335 & 1.420 \\
\hline & $\mathbf{B}_{2}$ & 19.327 & 8.154 & 162.192 & 1.600 \\
\hline & $\mathbf{B}_{3}$ & 19.340 & 8.183 & 162.869 & 1.603 \\
\hline & $\mathbf{B}_{4}$ & 19.219 & 8.017 & 160.879 & 1.398 \\
\hline & $\mathbf{B}_{5}$ & 19.259 & 8.038 & 160.985 & 1.402 \\
\hline & $\mathbf{B}_{6}$ & 19.239 & 8.093 & 161.817 & 1.610 \\
\hline \multicolumn{2}{|l|}{ L.S.D. 0.05} & 0.018 & 0.069 & 0.318 & 0.035 \\
\hline \multicolumn{2}{|l|}{ Solid wheat } & 18.187 & 7.930 & 158.97 & 1.437 \\
\hline \multicolumn{2}{|l|}{ Solid faba bean } & 19.372 & 7.955 & 159.845 & 1.465 \\
\hline \multicolumn{2}{|l|}{ Solid berseem } & 19.297 & 7.947 & 159.695 & 1.452 \\
\hline
\end{tabular}

chemical properties. The results show that soil $\mathrm{N}, \mathrm{P}, \mathrm{K}$ and $\mathrm{O}$. M. stocks increased $(\mathrm{P} \leq 0.05)$ with increasing mineral $\mathrm{N}$ fertilizer level from 60 to $90 \mathrm{~kg} \mathrm{~N} \mathrm{fed}^{-1}$. Application of $90 \mathrm{~kg} \mathrm{~N}$ fed $^{-1}$ gave the highest values of soil $\mathrm{N}, \mathrm{P}, \mathrm{K}$ and $\mathrm{O}$. M. contents compared with the others treatments. These results may be due to an increase in $\mathrm{N}$ fertilizer application which stabilize organic matter and retard the mineralization of older soil organic matter (Hagedorn et al., 2003). Accordingly, the lowest level of mineral $\mathrm{N}$ fertilizer influenced strongly soil O. M. and led to an environmental imbalance between soil biological and chemical processes reflected on action exchange capacity. In this concern,
Murphy (2015) found that soil organic matter can contribute to soil quality by aggregate stability and soil porosity, water-holding capacity especially available water, and action exchange capacity.

\subsubsection{Intercropping patterns}

Data in Table (2) show significant differences in soil N, P, K and O. M. stocks. The highest values $(P \leq 0.05)$ of these traits were observed by intercropping pattern $100 \%$ wheat + $40 \%$ faba bean, meanwhile the lowest values of soil $\mathrm{N}, \mathrm{P}, \mathrm{K}$ and $\mathrm{O}$. M. were obtained by intercropping pattern $100 \%$ wheat $+20 \%$ fahl berseem. These results reveal that legume the component in the intercrops had important role 
in the available soil contents that could increase soil carbon which may contribute to better soil structure (Gibson et al., 2006).

It is important to mention that soil $\mathrm{N}$ stock of the rhizosphere of intercropped wheat roots was increased by increasing the plant density of legume component from 20 to $30 \%$ of the sole culture. Moreover, it is expected that the intercrops will alter the dynamics of organic matter turnover and the rate of nutrient cycling within the soil (Arshad et al., 2016). These results could be due to an increase in plant density of the intercropped fahl berseem or faba bean from 20 to $40 \%$ of sole culture increased intra-specific competition between plants of legume component more than competition between plants of the intercrops that differed in their competitive ability for basic growth resources. Moreover, it is known that limited plant-available $\mathrm{P}$ is associated with a more horizontal root angle in bean, placing roots in surface soil where $\mathrm{P}$ can accumulate because it is highly immobile. These results are similar to those obtained by Abdel-Wahab et al. (2016) who noticed that the residual effect of the legume crops had positive effects on soil $\mathrm{N}, \mathrm{P}$ and $\mathrm{K}$ nutrients.

\subsubsection{Interaction between mineral $\mathbf{N}$ fertilizer levels and intercropping patterns}

Soil N, P, K and O. M. stocks of the rhizosphere of wheat roots were affected significantly by the interaction between mineral $\mathrm{N}$ fertilizer levels and intercropping patterns in the combined data across the two seasons (Table 2). Intercropping pattern $100 \%$ wheat $+40 \%$ faba bean with the application of $90 \mathrm{~kg} \mathrm{~N}$ fad ${ }^{-1}$ had the highest values of soil N, P, K and O. M., meanwhile the lowest values of soil chemical properties were obtained by intercropping pattern $100 \%$ wheat $+20.0 \%$ fahl berseem that received either 60 or $75 \mathrm{~kg} \mathrm{~N} \mathrm{fed}^{-1}$.

\subsection{Soil biological analyses}

\subsubsection{Mineral N fertilizer levels}

Total count of bacteria, Azotobacter, Azospirillum and phosphate solubilizing bacteria were affected significantly by $\mathrm{N}$ fertilizer levels (Table 3). Increasing mineral $\mathrm{N}$ fertilizer level from 60 to $75 \mathrm{~kg} \mathrm{~N} \mathrm{fad}^{-1}$ increased $(\mathrm{P} \leq 0.05)$ all the previous traits, meanwhile the lowest values of the biological soil properties were obtained by decreasing mineral $\mathrm{N}$ fertilizer level at $60 \mathrm{~kg} \mathrm{~N}$ $\mathrm{fed}^{-1}$. Soil or rhizosphere organisms include total, spore-forming .Certainly, there was a wide range of bacterial community which can be affected by mineral $\mathrm{N}$ fertilizer (Campbell et al.
2010).The number of Azotobacter, Azospirillum and phosphate solubilizing bacteria in the rhizosphere of wheat roots had a change trend; first increased and then decreased with increasing mineral $\mathrm{N}$ fertilizer level, indicating that high mineral $\mathrm{N}$ level had a great inhibitory effect on the number of all the studied bacteria. These results could be attributed to application of $90 \mathrm{~kg} \mathrm{~N} \mathrm{fed}{ }^{-1}$ affected negatively all the studied traits of soil biological properties and there by PGPR becomes lazy in the rhizosphere of wheat roots (Sheha et al. (2015). These results show that application of $75 \mathrm{~kg} \mathrm{~N}^{-1}$ can improve soil nutrients availability through bacterial activity in the experimental soil. Nitrogen fixing bacteria, besides fixing $\mathrm{N}$, solubilize $\mathrm{P}$ due to the production of organic acids and enzymes (Kumar and Narula 1999).

\subsubsection{Intercropping patterns}

Total count of bacteria, Azotobacter, Azospirillum and phosphate solubilizing bacteria were affected significantly by intercropping patterns (Table 3$)$. The highest values $(\mathrm{P} \leq 0.05)$ of all the previous traits were observed by intercropping pattern $100 \%$ wheat $+30 \%$ faba bean., meanwhile the lowest values of these traits were obtained by intercropping pattern $100 \%$ wheat $+20 \%$ fahl berseem .

These results could be due to intercropping the legume crops with wheat changed soil bacterial activity by promoting PGPR and phosphate solubilizing bacteria. It has been observed that the roots of intercrops freely intermingle resulting in complementary interactions between the root systems. It seems that plant-microbe interactions in the rhizosphere of wheat roots were increased by increasing the plant density of legume component from 20 to $30 \%$ of the sole culture. Certainly, the rhizosphere is a complex environment where roots interact with physical, chemical and biological properties of the soil, and is influenced by the presence and activity of roots (Richardson et al., 2009).

\subsubsection{Interaction between $\mathbf{N}$ fertilizer levels and intercropping patterns}

Total counts of bacteria, Azotobacter, Azospirillum and phosphate solubilizing bacteria were affected significantly by the interaction between mineral $\mathrm{N}$ fertilizer levels and intercropping patterns in the combined data across the two seasons (Table 3). Intercropping pattern $100 \%$ wheat $+30 \%$ faba bean with application of $75 \mathrm{~kg} \mathrm{~N} \mathrm{fed}^{-1}$ had the highest 
Table (3): Effect of $\mathbf{N}$ fertilizer levels, intercropping patterns and their interaction on some soil biological properties, combined data across 2013/2014 and 2014/2015.

\begin{tabular}{|c|c|c|c|c|c|}
\hline \multicolumn{2}{|c|}{ Traits } & $\begin{array}{c}\text { Total } \\
\text { count } \\
\left(\text { cfu } \times 10^{5}\right)\end{array}$ & $\begin{array}{l}\text { Azotobacter } \\
\left(\text { cfu } \times 1^{5}\right)\end{array}$ & $\begin{array}{l}\text { Azospirillium } \\
\quad\left(\text { cfu } x 1^{5}\right)\end{array}$ & $\begin{array}{c}\text { Phosphate } \\
\text { solubilizing } \\
\text { bacteria } \\
(\text { cfu x 10 }) \\
\end{array}$ \\
\hline \multicolumn{6}{|c|}{ Nitrogen fertilizer levels } \\
\hline \multicolumn{2}{|l|}{$60 \mathrm{~kg} \mathrm{fed}^{-1}\left(\mathbf{F}_{1}\right)$} & 83.342 & 1.709 & 3.842 & 2.533 \\
\hline \multicolumn{2}{|l|}{$75 \mathrm{~kg} \mathrm{fed}^{-1}\left(\mathbf{F}_{2}\right)$} & 89.700 & 2.287 & 4.470 & 4.586 \\
\hline \multicolumn{2}{|l|}{$90 \mathrm{~kg} \mathrm{fed}^{-1}\left(\mathbf{F}_{\mathbf{3}}\right)$} & 86.431 & 2.086 & 4.327 & 4.009 \\
\hline \multicolumn{2}{|l|}{ L.S.D. 0.05} & 3.219 & 0.094 & 0.146 & 0.019 \\
\hline \multicolumn{6}{|l|}{ Intercropping } \\
\hline \multicolumn{2}{|c|}{$100 \%$ wheat $+20 \%$ faba bean $\left(\mathbf{B}_{1}\right)$} & 88.349 & 1.683 & 4.226 & 3.477 \\
\hline \multicolumn{2}{|c|}{$100 \%$ wheat $+30 \%$ faba bean $\left(\mathbf{B}_{2}\right)$} & 119.961 & 2.233 & 4.795 & 4.188 \\
\hline \multicolumn{2}{|c|}{$100 \%$ wheat $+40 \%$ faba bean $\left(\mathbf{B}_{3}\right)$} & 106.744 & 2.108 & 4.156 & 3.992 \\
\hline \multicolumn{2}{|c|}{$100 \%$ wheat $+20 \%$ fahl berseem $\left(\mathbf{B}_{4}\right)$} & 56.217 & 1.734 & 3.689 & 3.212 \\
\hline \multicolumn{2}{|c|}{$100 \%$ wheat $+30 \%$ fahl barseem $\left(\mathbf{B}_{5}\right)$} & 73.744 & 2.173 & 4.178 & 3.744 \\
\hline \multicolumn{2}{|c|}{$100 \%$ wheat $+40 \%$ fahl berseem $\left(\mathbf{B}_{6}\right)$} & 73.533 & 1.998 & 4.235 & 3.644 \\
\hline \multicolumn{2}{|l|}{ L.S.D. 0.05} & 2.082 & 0.114 & 0.069 & 0.049 \\
\hline \multicolumn{6}{|l|}{ Interaction } \\
\hline \multirow{6}{*}{$60 \mathrm{~kg} \mathrm{fed}^{-1}\left(\mathbf{F}_{1}\right)$} & $\mathbf{B}_{1}$ & 84.533 & 1.185 & 3.388 & 2.180 \\
\hline & $\mathbf{B}_{2}$ & 101.350 & 2.368 & 4.575 & 2.688 \\
\hline & $\mathbf{B}_{3}$ & 114.983 & 2.110 & 4.125 & 2.928 \\
\hline & $\mathbf{B}_{4}$ & 55.867 & 0.925 & 2.925 & 2.088 \\
\hline & $\mathbf{B}_{5}$ & 71.250 & 1.845 & 4.063 & 2.585 \\
\hline & $\mathbf{B}_{6}$ & 72.067 & 1.820 & 3.978 & 2.730 \\
\hline \multirow[t]{6}{*}{$75 \mathrm{~kg} \mathrm{fed}^{-1}\left(\mathbf{F}_{2}\right)$} & $\mathbf{B}_{1}$ & 93.800 & 2.185 & 4.780 & 4.738 \\
\hline & $\mathbf{B}_{2}$ & 125.483 & 3.193 & 5.388 & 5.155 \\
\hline & $\mathbf{B}_{3}$ & 110.400 & 2.500 & 3.763 & 4.818 \\
\hline & $\mathbf{B}_{4}$ & 57.500 & 1.380 & 4.415 & 4.180 \\
\hline & $\mathbf{B}_{5}$ & 76.450 & 2.370 & 3.983 & 4.338 \\
\hline & $\mathbf{B}_{6}$ & 74.567 & 2.095 & 4.488 & 4.288 \\
\hline \multirow[t]{6}{*}{$90 \mathrm{~kg} \mathrm{fed}^{-1}\left(\mathbf{F}_{\mathbf{3}}\right)$} & $\mathbf{B}_{1}$ & 87.900 & 1.588 & 3.900 & 3.513 \\
\hline & $\mathbf{B}_{2}$ & 108.483 & 2.803 & 5.030 & 4.720 \\
\hline & $\mathbf{B}_{3}$ & 119.417 & 2.440 & 4.578 & 4.228 \\
\hline & $\mathbf{B}_{4}$ & 55.283 & 1.303 & 3.728 & 3.367 \\
\hline & $\mathbf{B}_{5}$ & 73.533 & 2.305 & 4.488 & 4.310 \\
\hline & $B_{6}$ & 73.967 & 2.078 & 4.238 & 3.913 \\
\hline \multicolumn{2}{|l|}{ L.S.D. 0.05} & 3.607 & 0.197 & 0.120 & 0.085 \\
\hline \multicolumn{2}{|l|}{ Solid wheat } & 74.50 & 1.55 & 3.591 & 2.484 \\
\hline \multicolumn{2}{|c|}{ Solid faba bean } & 120.417 & 2.880 & 4.470 & 4.310 \\
\hline \multicolumn{2}{|c|}{ Solid berseem fahl } & 88.315 & 2.173 & 4.238 & 3.941 \\
\hline
\end{tabular}

values of Azotobacter, Azospirillum and phosphate solubilizing bacteria, meanwhile the lowest values of soil biological properties were obtained by intercropping pattern $100 \%$ wheat + $20.0 \%$ fahl berseem that received $60 \mathrm{~kg} \mathrm{~N} \mathrm{fed}^{-1}$. However, intercropping pattern $100 \%$ wheat + $40.0 \%$ fahl berseem that received 60 or $90 \mathrm{~kg} \mathrm{~N}$ $\mathrm{fed}^{-1}$ achieved the least total count of bacteria compared with the others, probably due to the heterogeneity of the soil physicochemical environment and the abundance of inactive or dormant organisms. It is known that the interaction between soil type, plant species and rhizosphere localization of bacterial community affects bacterial community composition
(Marschner et al.,2001). The medium plant density of intercropped fahl berseem or faba bean interacted positively with application of 75 $\mathrm{kg} \mathrm{N}$ fed $^{-1}$ and furnished better above and below - ground conditions for enhancement of PGPR and phosphate solubilizing bacteria compared to the other treatments. These data show that each of these two factors act dependently on the total count of bacteria, Azotobacter, Azospirillum and phosphate solubilizing bacteria meaning that mineral $\mathrm{N}$ fertilizer levels responded differently $(P \leq 0.05)$ to mineral $\mathrm{N}$ fertilizer for soil biological properties.

\subsubsection{Correlation coefficients}

Simple correlation among total count and its 
relation characters over the two $(\mathrm{n}=10)$ is present in (Table 4) The results of correlation coefficients between traits showed that total count had a positive and significant correlation with Azotobacter $(\mathrm{r}=0.713 * *)$, Azotobacter with Azospirilum $\left(\mathrm{r}=0.702^{* *}\right)$, Phosphate $(\mathrm{r}=$ $\left.0.713^{* *}\right)$ and Nitrogen ( $\left.\mathrm{r}=0.604^{* *}\right)$, Azospirilum ( $\mathrm{r}=0.672 * *)$, Phosphate with Nitrogen $\left(\mathrm{r}=0.834^{* *}\right)$, at $1 \%$ probability levels and Azospirilum had a positive and significant correlation with Nitrogen $(0.487)$ at $5 \%$ probability levels.

Table (4): Simple correlation coefficients between microbial soil content trait:

\begin{tabular}{|l|l|l|l|l|l|}
\hline Traits & \multicolumn{1}{|c|}{ N } & \multicolumn{1}{|c|}{ PH } & \multicolumn{1}{|c|}{ AS } & AT & TC \\
\hline N & 1 & & & & \\
\hline PH & $\mathbf{0 . 8 3 4}^{* *}$ & 1 & & & \\
\hline AS & $\mathbf{0 . 4 8 7}^{* *}$ & $\mathbf{0 . 6 7 2}^{* *}$ & 1 & & \\
\hline AT & $\mathbf{0 . 6 0 4}^{* *}$ & $\mathbf{0 . 7 1 3}^{* *}$ & $\mathbf{0 . 7 0 2}^{* *}$ & 1 & \\
\hline TC & $\mathbf{0 . 4 4 1}^{*}$ & $\mathbf{0 . 3 9 1}$ & $\mathbf{0 . 3 9 6}$ & $\mathbf{0 . 7 1 3}^{* *}$ & 1 \\
\hline
\end{tabular}

Abbreviations: - N: Nitrogen , PH: Phosphate, AS : Azospirilum , AT : Azotobacter and TC : Total count

\subsection{Grain yield of wheat and its attributes. 3.3.1. Mineral $N$ fertilizer levels.}

Plant height, the number of spikes $/ \mathrm{m}^{2}$, number of kernels/spike, grain and straw yields $\mathrm{fad}^{-1}$ were affected significantly by $\mathrm{N}$ fertilizer levels, meanwhile spike length and 1000- kernel weight were not affected (Table 5). Increasing $\mathrm{N}$ fertilizer level from 60 to $75 \mathrm{~kg} \mathrm{~N}$ fed $^{-1}$ increased $(\mathrm{P} \leq 0.05)$ plant height, the number of spikes $/ \mathrm{m}^{2}$, number of kernels/spike, grain and straw yields $\mathrm{fad}^{-1}$ but these traits except plant height were increased by increasing $\mathrm{N}$ fertilizer level from $75-90 \mathrm{~kg} \mathrm{~N} \mathrm{fed}{ }^{-1}$. This result is in agreement with those observed by El Naggar et al. (1991). Increasing $\mathrm{N}$ fertilizer level from 60 to $75 \mathrm{~kg} \mathrm{~N}$ $\mathrm{fed}^{-1}$ led to significant increments in the number of spikes $\mathrm{m}^{-2}$ by $3.52 \%$ number of kernels/spike by $6.00 \%$ and grain yield fed $^{-1}$ by $7.63 \%$ compared with the lowest $\mathrm{N}$ level in the combined data across the two growing seasons. These results are in agreement with the findings of Sharief et al.(1998) who reported that using $75 \mathrm{~kg} \mathrm{~N} \mathrm{fed}^{-1}$ resulted in a significant increase in plant height, No. of tillers $\mathrm{m}^{2}$, spike length, spike weight, No. of grains per spike, grain weight spike $^{-1}$ and 100 grain weight which in turn increased,grain, straw and biological yields fed ${ }^{-1}$. These results could be due to application of 90 $\mathrm{kg} \mathrm{N}$ fed $^{-1}$ may have influenced negatively soil chemical and biological properties (Tables 2 and 3) which caused rapid cell division of wheat plant, thereby lengthened the vegetative stage and delayed the reproductive stage of the plant. These results indicate that PGPR and phosphate solubilizing bacteria has contributed to decrease intra-specific competition between wheat plants for soil N, P and K and facilitated these nutrients uptake for wheat plants. Accordingly, it is expected that growth resources such as water and nutrients were more completely absorbed and converted to crop biomass during growth and development stages of wheat plants in case of $75 \mathrm{~kg} \mathrm{~N}^{-\mathrm{fed}^{-1}}$ than those received the others. These results imply that application of $75 \mathrm{~kg} \mathrm{~N}$ fed $^{-1}$ furnished suitable edaphic conditions to roots of wheat plants through soil chemical and biological properties during the early growth stages of the cereal component which decreased intra-specific competition between wheat plants for available environmental conditions.

\subsubsection{Intercropping patterns.}

Plant height, spike length, the number of spikes $\mathrm{m}^{-2}$, number of kernels/spike, $1000-$ kernel weight, grain and straw yields fed ${ }^{-1}$ were affected significantly by intercropping patterns (Table 5). Intercropping pattern $100 \%$ wheat + $20 \%$ fahl berseem increased $(P \leq 0.05)$ spike length, 1000 - kernel weight and the number of kernels spike ${ }^{-1}$, followed by number of spikes $/ \mathrm{m}^{2}$ and grain yields $\mathrm{fed}^{-1}$ in intercropping pattern $100 \%$ wheat $+20 \%$ faba bean meanwhile the lowest values of number of spikes $\mathrm{m}^{-2}$, number of kernels spike ${ }^{-1}, 1000$ - kernel weight and grain yields fed $^{-1}$ were obtained by intercropping pattern $100 \%$ wheat $+40 \%$ fahl berseem. These findings are in agreement with those obtained by Eskandari (2011). The present results show that intercropping systems had a significant effect on environmental resources consumption, where intercropping systems had more light interception and water, and nutrient uptake compared to sole crops, suggesting the complementarity effect of intercropping components in resources consumption. The ability of wheat and bean was different in intercropping systems in absorbing nutrients because of their differences in root morpholpgy and action exchange capacity.

These results are in accordance with those observed by Song et al. (2007) who showed that intercropping has significant effects on microbiological and chemical properties in the rhizosphere, which may contribute to the yield enhancement by intercropping. 
Table (5): Effect of $\mathbf{N}$ fertilizer levels, intercropping patterns and their interaction on wheat grain yield and its attributes, combined data across 2013/2014 and 2014/2015.

\begin{tabular}{|c|c|c|c|c|c|c|c|c|}
\hline \multicolumn{2}{|l|}{ Traits } & $\begin{array}{l}\text { Plant } \\
\text { height } \\
\text { (cm) }\end{array}$ & $\begin{array}{l}\text { Spike } \\
\text { length } \\
\text { (cm) }\end{array}$ & $\begin{array}{l}\text { Spikes/ } \\
\text { m}^{2} \\
(\text { No) }\end{array}$ & $\begin{array}{l}1000 \\
\text { kernels } \\
\text { (g) }\end{array}$ & $\begin{array}{l}\text { Kernels / } \\
\text { Spike } \\
\text { (No) }\end{array}$ & $\begin{array}{l}\text { Grain } \\
\text { yield } \\
\text { (ton/fed) }\end{array}$ & $\begin{array}{l}\text { Straw } \\
\text { yield } \\
\text { (ton/fed) }\end{array}$ \\
\hline \multicolumn{9}{|c|}{ Nitrogen fertilizer levels } \\
\hline \multicolumn{2}{|l|}{$75 \mathrm{~kg} \mathrm{fed}^{-1}\left(\mathbf{F}_{1}\right)$} & 95.16 & 9.39 & 411 & $\begin{array}{l}\mathbf{4 0 . 1} \\
47.8\end{array}$ & $\begin{array}{l}4.01 \\
50.15\end{array}$ & 2.686 & 4.230 \\
\hline \multicolumn{2}{|l|}{$90 \mathrm{~kg} \mathrm{fed}^{-1}\left(\mathbf{F}_{\mathbf{1}}\right)$} & 95.89 & 9.28 & 367 & 45.8 & 47.25 & 2.338 & 4.179 \\
\hline L.S.D. 0.05 & & 1.175 & NS & 8.726 & NS & 1.164 & 0.038 & 0.055 \\
\hline \multicolumn{9}{|l|}{ Intercropping } \\
\hline \multicolumn{2}{|c|}{$100 \%$ wheat $+20 \%$ faba bean $\left(\mathbf{B}_{1}\right)$} & 93.71 & 9.50 & 428 & 47.4 & 51.49 & 2.677 & 3.818 \\
\hline \multicolumn{2}{|c|}{$100 \%$ wheat $+30 \%$ faba bean $\left(\mathbf{B}_{2}\right)$} & 93.11 & 9.18 & 406 & 468 & 47.59 & 2.583 & 3.440 \\
\hline \multirow{2}{*}{\multicolumn{2}{|c|}{$\begin{array}{l}100 \% \text { wheat }+40 \% \text { faba bean }\left(\mathbf{B}_{3}\right) \\
100 \% \text { wheat }+20 \% \text { fahl berseem }\left(\mathbf{B}_{4}\right)\end{array}$}} & 93.87 & 8.87 & 380 & 46.0 & 45.39 & 2.486 & 3.334 \\
\hline & & 94.81 & 9.75 & 401 & 48.3 & 51.81 & 2.603 & 4.243 \\
\hline \multirow{2}{*}{\multicolumn{2}{|c|}{$\begin{array}{l}100 \% \text { wheat }+30 \% \text { fahl berseem }\left(\mathbf{B}_{5}\right) \\
100 \% \text { wheat }+40 \% \text { fahl berseem }\left(\mathbf{B}_{6}\right)\end{array}$}} & 95.33 & 9.44 & 383 & 47.3 & 48.57 & 2.399 & 4.370 \\
\hline & & 97.94 & 9.18 & 357 & 4.40 & 44.97 & 2.286 & 4.719 \\
\hline \multicolumn{2}{|l|}{ L.S.D. 0.05} & 1.794 & 0.455 & 9.492 & 1.94 & 1.272 & 0.066 & 0.149 \\
\hline \multicolumn{9}{|l|}{ Interaction } \\
\hline \multirow[t]{6}{*}{$\mathbf{F}_{1}$} & $\mathbf{B}_{1}$ & 90.67 & 9.58 & 409 & 47.1 & 51.01 & 2.647 & 3.656 \\
\hline & $\mathbf{B}_{2}$ & 93.33 & 9.23 & 406 & 46.3 & 49.04 & 2.632 & 3.242 \\
\hline & $\mathbf{B}_{3}$ & 95.83 & 8.87 & 387 & 44.9 & 44.52 & 2.578 & 3.139 \\
\hline & $\mathbf{B}_{4}$ & 91.60 & 9.80 & 388 & 47.6 & 50.69 & 2.498 & 3.609 \\
\hline & $\mathbf{B}_{5}$ & 92.50 & 9.39 & 388 & 46.6 & 45.48 & 2.377 & 3.669 \\
\hline & $\mathbf{B}_{6}$ & 95.83 & 8.92 & 359 & 44.1 & 43.11 & 2.237 & 4.009 \\
\hline \multirow[t]{6}{*}{$\mathbf{F}_{2}$} & $\mathbf{B}_{1}$ & 95.47 & 9.56 & 460 & 48.4 & 55.62 & 2.973 & 3.981 \\
\hline & $\mathbf{B}_{2}$ & 93.17 & 9.28 & 429 & 47.8 & 48.07 & 2.795 & 3.698 \\
\hline & $\mathbf{B}_{3}$ & 93.00 & 9.04 & 397 & 46.9 & 48.76 & 2.571 & 3.566 \\
\hline & $\mathbf{B}_{4}$ & 96.00 & 9.66 & 433 & 48.5 & 51.44 & 2.848 & 4.418 \\
\hline & $\mathbf{B}_{5}$ & 95.50 & 9.43 & 418 & 48.4 & 50.05 & 2.472 & 4.685 \\
\hline & $\mathbf{B}_{6}$ & 97.83 & 9.34 & 392 & 46.5 & 46.94 & 2.357 & 5.030 \\
\hline \multirow[t]{6}{*}{$\mathbf{F}_{3}$} & $\mathbf{B}_{1}$ & 95.00 & 9.37 & 415 & 46.7 & 48.85 & 2.435 & 3.818 \\
\hline & $\mathbf{B}_{2}$ & 92.83 & 9.03 & 383 & 46.4 & 45.70 & 2.321 & 3.380 \\
\hline & $\mathbf{B}_{3}$ & 92.50 & 8.72 & 356 & 46.1 & 42.88 & 2.308 & 3.299 \\
\hline & $\mathbf{B}_{4}$ & 96.83 & 9.78 & 382 & 48.6 & 51.01 & 2.463 & 4.703 \\
\hline & $\mathbf{B}_{5}$ & 98.00 & 9.49 & 345 & 46.8 & 50.18 & 2.350 & 4.756 \\
\hline & $\mathbf{B}_{6}$ & 100.17 & 9.27 & 320 & 41.3 & 44.87 & 2.265 & 5.120 \\
\hline \multicolumn{2}{|l|}{ L.S.D .05 F x B } & 3.107 & NS & 16.441 & NS & 2.204 & 0.115 & 0.258 \\
\hline \multicolumn{2}{|l|}{ Solid wheat } & 92.5 & 9.51 & 422 & 46.5 & 46.15 & 2.536 & 3.675 \\
\hline
\end{tabular}

\subsubsection{Interaction between $\mathbf{N}$ fertilizer levels and intercropping patterns}

Plant height, number of spikes $/ \mathrm{m}^{2}$, number of kernels/spike, grain and straw yields $\mathrm{fad}^{-1}$ were affected significantly by $\mathrm{N}$ fertilizer levels $\mathrm{x}$ intercropping patterns, meanwhile spike length and 1000 - kernel weight were not affected (Table 5). Intercropping pattern $100 \%$ wheat + $20 \%$ faba bean with the application of $75 \mathrm{~kg} \mathrm{~N}$ $\mathrm{fad}^{-1}$ had the highest values of the number of spikes $\mathrm{m}^{-2}$, no of kernels spike ${ }^{-1}$ and grain yield $\mathrm{fed}^{-1}$ meanwhile the lowest values of number of spikes $\mathrm{m}^{-2}$, number of kernels spike ${ }^{-1}$ and grain yields $\mathrm{fed}^{-1}$ were obtained by intercropping pattern $100 \%$ wheat $+40.0 \%$ fahl berseem that received either 60 or $90 \mathrm{~kg} \mathrm{~N}$ fed $^{-1}$ compered other treatments.
Although, the medium plant density of legume component contributed largely in enhancing PGPR and phosphate solubilizing bacteria in rhizosphere of wheat roots, but wheat attributes could be closely related to the amount of solar radiation during the growing season. Thus, it is expected that the least plant density of fahl berseem or faba bean integrated with $75 \mathrm{~kg}$ $\mathrm{N} \mathrm{fed}{ }^{-1}$ to activate the least quantity of PGPR and phosphate solubilizing bacteria that promoted efficiency of photosynthetic process of wheat plant indirectly by producing physiologically active gibberellins (GutierrezManero et al., 2001) and altering root growth via nutrient availability through mineralization (Fan et al.,2011). These results revealed that intercropping pattern $100 \%$ wheat $+20 \%$ faba 
bean or $100 \%$ wheat $+20 \%$ fahl berseem interacted with $75 \mathrm{~kg} \mathrm{~N} \mathrm{fed}^{-1}$ to decrease inter or intra-specific competition between plants of the intercrops or plants of wheat, respectively, for available environmental conditions. These data show that each of these two factors act dependently on plant height, the number of spikes $\mathrm{m}^{-2}$, number of kernels spike ${ }^{-1}$, grain and straw yields $\mathrm{fed}^{-1}$ meaning that mineral $\mathrm{N}$ fertilizer levels responded differently $(P \leq 0.05)$ to intercropping pattern for most the studied traits of wheat.

\subsubsection{Correlation coefficients}

In (Table 6) the results of correlation coefficients between the traits showed that number of spikes $\mathrm{m}^{-2}$ had a positive and significant correlation with kernels/spike weight $\left(\mathrm{r}=0.517^{*}\right)$ and No of kernels/spike $\left(\mathrm{r}=0.466^{*}\right)$, kernels/spike weight with 1000 kernels weight ( $\mathrm{r}$ $\left.=0.546^{*}\right)$ at $5 \%$ probability levels, and No of kernels/spike $(0.682 * *)$ at $1 \%$ probability levels. While spikes $\mathrm{m}^{-2}$ number had a negative with 1000 kernels weight $(r=-0.030)$.

\subsection{Quality of wheat grains}

\subsubsection{Mineral $\mathbf{N}$ fertilizer levels}

Grain $\mathrm{N}$ and protein contents were affected significantly by mineral $\mathrm{N}$ fertilizer levels in the combined analysis (Table 7). Increasing $\mathrm{N}$ fertilizer level from 60 to $75 \mathrm{~kg} \mathrm{~N}^{-1} \mathrm{~d}^{-1}$ increased $(P \leq 0.05)$ grain $\mathrm{N}$ and protein contents but it were decreased by increasing $\mathrm{N}$ fertilizer level from 75 to $90 \mathrm{~kg} \mathrm{~N}$ fed $^{-1}$. These results were due to increase in mineral $\mathrm{N}$ fertilizer level from 60 to $75 \mathrm{~kg} \mathrm{~N}$ fad $^{-1}$ improved soil chemical and biological properties (Tables 2 and 3 ) and reflected positively on $\mathrm{N}, \mathrm{P}$ and $\mathrm{K}$ status in the wheat crop. Obviously, excess application of mineral $\mathrm{N}$ fertilizer per fed was not economically efficient and reduced grain protein content. These results are in accordance with those obtained by Abedi et al.(2011) who studied the effect of $\mathrm{N}$ rate application $(0,120$, 240 and $360 \mathrm{~kg} \mathrm{~N} \mathrm{ha}^{-1}$ ) and $\mathrm{N}$ timing on grain yield, yield components, grain quality and protein banding pattern in different growth stages of wheat. They found that $240 \mathrm{~kg} \mathrm{~N} \mathrm{ha}^{-1}$ application in all timing treatments resulted in maximum grain protein content $(5.5 \mathrm{mg}$ protein $\mathrm{g}^{-1}$ grain).

\subsubsection{Intercropping patterns}

Grain $\mathrm{N}$ and protein contents were affected significantly by intercropping patterns in the combined analysis (Table 7). Intercropping pattern $100 \%$ wheat $+40 \%$ faba bean increased
$(P \leq 0.05)$ grain $\mathrm{N}$ and protein contents, meanwhile the lowest values of grain $\mathrm{N}$ and protein contents were obtained by intercropping pattern $100 \%$ wheat $+20 \%$ faba bean. These results were due to intercropping pattern $100 \%$ wheat $+40 \%$ faba bean improved soil chemical and biological properties (Tables2 \& 3) that reflected positively on grain $\mathrm{N}$ and protein contents of the wheat crop.

Similar results were observed by Sarunaite and Kadziuliene (2010) who reported that the significantly higher crude protein concentration was observed in the total intercrops grain yields compared with the sole wheat yield.

\subsubsection{Interaction between $\mathbf{N}$ fertilizer levels and intercropping patterns}

Grain $\mathrm{N}$ and protein contents were affected significantly by $\mathrm{N}$ fertilizer levels $\mathrm{x}$ intercropping patterns in the combined analysis (Table 7). Intercropping pattern $100 \%$ wheat + $40 \%$ faba bean with the application of $75 \mathrm{~kg} \mathrm{~N}$ $\mathrm{fed}^{-1}$ had the highest grain $\mathrm{N}$ and protein contents compared to other treatments, meanwhile the lowest values of grain $\mathrm{N}$ and protein contents were obtained by intercropping pattern $100 \%$ wheat $+20 \%$ faba bean that received either 60 or $90 \mathrm{~kg} \mathrm{~N}_{\text {fad }}{ }^{-1}$. These results show that each of these two factors act dependently on grain $\mathrm{N}$ and protein contents of wheat meaning that mineral $\mathrm{N}$ fertilizer levels responded differently $(P \leq 0.05)$ to mineral $\mathrm{N}$ fertilizer for grain $\mathrm{N}$ and protein contents of wheat. Similar results were observed by Tosti $e t$ al. (2016) who indicated that intercropping faba bean with wheat was a promising technique to improve the quality of organic wheat in Mediterranean areas and it had positive effect on both production quality (wheat protein concentration) and the environment (reduction of $\mathrm{N}$ leaching losses).

\subsection{Seed yields of fahl berseem and faba bean 3.5.1. Mineral $\mathbf{N}$ fertilizer levels}

Seed yields of fahl berseem and faba bean were affected significantly by $\mathrm{N}$ fertilizer levels (Table 8). Increasing $\mathrm{N}$ fertilizer level from 60 To $75 \mathrm{~kg} \mathrm{~N}$ fed $^{-1}$ per unit area increased $(\mathrm{P} \leq 0.05)$ seed yield of fahl berseem or faba bean but seed yield of faba bean was decreased by increasing $\mathrm{N}$ fertilizer level from 75 to $90 \mathrm{~kg} \mathrm{~N}$ $\mathrm{fed}^{-1}$. Clearly, it is likely that application of 90 $\mathrm{kg} \mathrm{N}$ fed $^{-1}$ lengthened the vegetative stage of faba bean plant and promoted development of the above ground green tissues more than reproductive organs and could be translated 
Table (6): Simple correlation coefficients between No. of Spike $\mathrm{m}^{-2}$ and its component traits.

\begin{tabular}{|l|l|l|l|l|}
\hline \multicolumn{1}{|c|}{ Traits } & $\begin{array}{c}\text { Spike } \mathbf{~ m}^{-2} \\
(\mathbf{N o})\end{array}$ & \multicolumn{1}{|c|}{$\begin{array}{c}\text { kernels/spike } \\
(\mathbf{g})\end{array}$} & \multicolumn{1}{c|}{$\begin{array}{c}\mathbf{1 0 0 0} \text { kernels } \\
(\mathbf{g})\end{array}$} & $\begin{array}{c}\text { Kernels/spike } \\
(\mathbf{N o})\end{array}$ \\
\hline Spike $\mathbf{~ m}^{-\mathbf{2}}$ (NO) & 1 & \multicolumn{1}{|c|}{} & & \\
\hline kernels/spike ( g) & $0.517^{*}$ & 1 & 1 & \\
\hline 1000 kernels(g) & -0.030 & $0.546^{*}$ & -0.003 & 1 \\
\hline Kernels/spike (No) & $0.466^{*}$ & $0.682^{* *}$ & & \\
\hline
\end{tabular}

Table (7): Effect of $\mathbf{N}$ fertilizer levels, intercropping patterns and their interaction on quality of wheat grains, combined data across 2013/2014 and 2014/2015.

\begin{tabular}{|c|c|c|c|}
\hline \multicolumn{2}{|c|}{ Traits } & $\begin{array}{l}\text { Grain } \mathbf{N} \text { content } \\
(\%)\end{array}$ & $\begin{array}{l}\text { Grain protein } \\
\text { content }(\%)\end{array}$ \\
\hline \multicolumn{4}{|c|}{ Nitrogen fertilizer levels } \\
\hline \multicolumn{2}{|c|}{$60 \mathrm{~kg} \mathrm{fed}^{-1}\left(\mathbf{F}_{\mathbf{1}}\right)$} & 1.221 & 6.962 \\
\hline \multicolumn{2}{|c|}{$75 \mathrm{~kg} \mathrm{fed}^{-1}\left(\mathbf{F}_{2}\right)$} & 1.321 & 7.529 \\
\hline \multicolumn{2}{|c|}{$90 \mathrm{~kg} \mathrm{fed}^{-1}\left(\mathbf{F}_{\mathbf{3}}\right)$} & 1.288 & 7.343 \\
\hline \multicolumn{2}{|c|}{ L.S.D. 0.05 } & 0.007 & 0.037 \\
\hline \multicolumn{4}{|c|}{ Intercropping } \\
\hline \multicolumn{2}{|c|}{$100 \%$ wheat $+20 \%$ faba bean $\left(B_{1}\right)$} & 1.302 & 7.423 \\
\hline \multicolumn{2}{|c|}{$100 \%$ wheat $+30 \%$ faba bean $\left(B_{2}\right)$} & 1.321 & 7.530 \\
\hline \multicolumn{2}{|c|}{$100 \%$ wheat $+40 \%$ faba bean $\left(\mathrm{B}_{3}\right)$} & 1.357 & 7.733 \\
\hline \multicolumn{2}{|c|}{$100 \%$ wheat $+20 \%$ fahl berseem $\left(B_{4}\right)$} & 1.196 & 6.818 \\
\hline \multicolumn{2}{|c|}{$100 \%$ wheat $+30 \%$ fahl barseem $\left(B_{5}\right)$} & 1.228 & 7.001 \\
\hline \multicolumn{2}{|c|}{$100 \%$ wheat $+40 \%$ fahl berseem $\left(B_{6}\right)$} & 1.257 & 7.163 \\
\hline \multicolumn{2}{|c|}{ L.S.D. 0.05} & 0.007 & 0.041 \\
\hline \multicolumn{4}{|c|}{ Interaction } \\
\hline \multirow{6}{*}{ F1 } & B1 & 1.222 & 6.964 \\
\hline & B2 & 1.252 & 7.134 \\
\hline & B3 & 1.315 & 7.496 \\
\hline & B4 & 1.150 & 6.555 \\
\hline & B5 & 1.168 & 6.659 \\
\hline & B6 & 1.222 & 6.963 \\
\hline \multirow{6}{*}{ F2 } & B1 & 1.353 & 7.714 \\
\hline & B2 & 1.372 & 7.819 \\
\hline & B3 & 1.403 & 7.999 \\
\hline & B4 & 1.238 & 7.059 \\
\hline & B5 & 1.273 & 7.258 \\
\hline & B6 & 1.285 & 7.325 \\
\hline \multirow{6}{*}{ F3 } & B1 & 1.332 & 7.591 \\
\hline & B2 & 1.340 & 7.638 \\
\hline & B3 & 1.352 & 7.704 \\
\hline & B4 & 1.200 & 6.840 \\
\hline & B5 & 1.243 & 7.087 \\
\hline & B6 & 1.263 & 7.201 \\
\hline \multicolumn{2}{|c|}{ L.S.D. 0.05} & 0.012 & 0.071 \\
\hline \multicolumn{2}{|c|}{ Solid wheat } & 1.302 & 7.421 \\
\hline
\end{tabular}

into alteration of plant height growth rate and increased lodging percentage (Lincoln and Edvardo, 2006; Bozorgi et al., 2011). With respect to seed yield of fahl berseem, there were no significant differences between 75 and $90 \mathrm{~kg}$ $\mathrm{N}$ fed $^{-1}$ for this trait. Similar results were obtained by Abdel-Wahab and Elmanzalawy (2016). The recommended mineral $\mathrm{N}$ fertilizer rate of wheat plants and improved quality of wheat grains without any negative effects on quality of intercropped faba bean seeds.

\subsubsection{Intercropping patterns}

Seed yields of fahl berseem or faba bean were affected significantly by intercropping patterns (Table 8). Intercropping patterns $100 \%$ wheat $+40 \%$ barseem fahl or faba bean had the 
Table (8): Effect of $\mathbf{N}$ fertilizer levels, intercropping patterns and their interaction on seed yields of fahl berseem and faba bean, combined data across 2013/2014 and 2014/2015.

\begin{tabular}{|c|c|c|c|}
\hline \multicolumn{2}{|c|}{$\begin{array}{rr}\text { Traits } \\
\end{array}$} & $\begin{array}{l}\text { Seed yield of faba } \\
\text { bean }\left(\mathrm{kg} \mathrm{fed}^{-1}\right)\end{array}$ & $\begin{array}{l}\text { Seed yield of fahl } \\
\text { berseem }\left(\mathrm{kgfed}^{-1}\right)\end{array}$ \\
\hline \multicolumn{2}{|l|}{$60 \mathrm{~kg} \mathrm{~N}^{\mathrm{Ned}}{ }^{-1}$} & 178.8 & 47.9 \\
\hline \multicolumn{2}{|l|}{$75 \mathrm{~kg} \mathrm{~N}$ fed $^{-1}$} & 201.9 & 56.1 \\
\hline \multicolumn{2}{|l|}{$90 \mathrm{~kg} \mathrm{~N} \mathrm{fed}^{-1}$} & 183.0 & 55.7 \\
\hline \multicolumn{2}{|l|}{ L.S.D. 0.05} & 1.25 & 1.84 \\
\hline \multicolumn{2}{|c|}{$100 \%$ wheat $+20 \%$ faba bean or fahl berseem } & 150.9 & 49.6 \\
\hline \multicolumn{2}{|c|}{$100 \%$ wheat $+30 \%$ faba bean or fahl berseem } & 194.3 & 53.1 \\
\hline \multicolumn{2}{|c|}{$100 \%$ wheat $+40 \%$ faba bean or fahl berseem } & 218.5 & 57.3 \\
\hline \multicolumn{2}{|c|}{ L.S.D. 0.05 Intercropping systems } & 2.06 & 1.41 \\
\hline \multirow{3}{*}{$60 \mathrm{~kg} \mathrm{~N} \mathrm{fed}^{-1}$} & $100 \%$ wheat $+20 \%$ faba bean or fahl berseem & 144.0 & 43.0 \\
\hline & $100 \%$ wheat $+30 \%$ faba bean or fahl berseem & 178.5 & 47.5 \\
\hline & $100 \%$ wheat $+40 \%$ faba bean or fahl berseem & 213.5 & 53.0 \\
\hline \multirow{3}{*}{$75 \mathrm{~kg} \mathrm{~N} \mathrm{fed}^{-1}$} & $100 \%$ wheat $+20 \%$ faba bean or fahl berseem & 159.5 & 53.0 \\
\hline & $100 \%$ wheat $+30 \%$ faba bean or fahl berseem & 211.5 & 57.0 \\
\hline & $100 \%$ wheat $+40 \%$ faba bean or fahl berseem & 234.5 & 60.0 \\
\hline \multirow{3}{*}{$90 \mathrm{~kg} \mathrm{~N} \mathrm{fed}^{-1}$} & $100 \%$ wheat $+20 \%$ faba bean or fahl berseem & 149.0 & 53.0 \\
\hline & $100 \%$ wheat $+30 \%$ faba bean or fahl berseem & 194.0 & 55.0 \\
\hline & $100 \%$ wheat $+40 \%$ faba bean or fahl berseem & 207.5 & 59.0 \\
\hline \multicolumn{2}{|c|}{ L.S.D. 0.05 Interaction } & 3.56 & N.S. \\
\hline \multicolumn{2}{|c|}{ Sole culture } & 964 & 401 \\
\hline
\end{tabular}

highest $(P \leq 0.05)$ seed yield of legume component, meanwhile the lowest seed yield of legume component was obtained by intercropping patterns $100 \%$ wheat $+20 \%$ barseem fahl or faba bean.Obviously, plant density of fahl berseem or faba bean played a major role in seed yield per unit area under intercropping conditions and gave the highest seed yield of legume component. Dahmardeh et al. (2010) revealed that increasing plant density from 12.5 to 20 plant $\mathrm{m}^{-2}$ increased significantly economical yield. Also, Al-Suhaibani et al., (2013) found that increasing plant density resulted in a significant decrease in all yield components of individual plants but seed yield increased with densities up to 8 plants dripper ${ }^{-1}$. Kandil and Sharief, (2016) reported that total yield of Egyptian clover per unit area tended to increase with seeding rates.

\subsubsection{Interaction between $\mathbf{N}$ fertilizer levels and intercropping patterns}

Seed yield of faba bean fed ${ }^{-1}$ was affected significantly by the interaction between $\mathrm{N}$ fertilizer levels and intercropping patterns, meanwhile seed yield of fahl berseem fed ${ }^{-1}$ was not affected (Table 8). Intercropping pattern $100 \%$ wheat $+40 \%$ faba bean with the application of $75 \mathrm{~kg} \mathrm{~N}$ fed $^{-1}$ had the highest seed yield fed $^{-1}$, but the reverse was true by intercropping pattern $100 \%$ wheat $+20 \%$ faba bean that received either 60 or $90 \mathrm{~kg} \mathrm{~N} \mathrm{fed}^{-1}$.
These data reveal that there were effect $(\mathrm{P} \leq 0.05)$ of mineral $\mathrm{N}$ fertilizer levels $\mathrm{x}$ intercropping patterns on seed yield of faba bean $\mathrm{fed}^{-1}$. In this concern, interaction effect of $\mathrm{N}$ and planting density on seed yield was significant and maximum yield was obtained from application of $90 \mathrm{~kg} \mathrm{ha}^{-1} \mathrm{~N}$ and the highest level of density (Golabi and Lak, 2005). Also, Khamooshi et al., (2012) showed that the effect of plant density and $\mathrm{N}$ were significant on faba bean seed yield.

\subsection{Quality of fahl berseem and faba bean seeds}

\subsubsection{Mineral $\mathbf{N}$ fertilizer levels}

Seed $\mathrm{N}$ and protein contents of fahl berseem and faba bean were affected significantly by $\mathrm{N}$ fertilizer levels in the combined analysis (Table 9). Increasing mineral $\mathrm{N}$ fertilizer level from 60 to $75 \mathrm{~kg} \mathrm{~N}^{-1}$ increased $(\mathrm{P} \leq 0.05)$ seed $\mathrm{N}$ and protein contents of fahl berseem or faba bean but it were decreased by increasing mineral $\mathrm{N}$ fertilizer level from 75 to $90 \mathrm{~kg} \mathrm{~N}^{-1} \mathrm{fed}^{-1}$. These results were attributed to the application of the highest mineral $\mathrm{N}$ fertilizer level affected negatively all the studied traits of soil biological properties and thereby PGPR becomes lazy compared with the other treatments (Table 2). Similar results were abstained by Abdel-Wahab and Elmanzalawy (2016), the recommended mineral $\mathrm{N}$ fertilizer rate of wheat plants and improved quality of wheat grains without any Negative effects on quality of intercropped faba 
Table (9): Effect of $\mathbf{N}$ fertilizer levels, intercropping patterns and their interaction on quality of faba bean and fahl berseem seeds, combined data across 2013/2014 and 2014/2015.

\begin{tabular}{|c|c|c|c|c|c|}
\hline \multirow{2}{*}{\multicolumn{2}{|c|}{$\begin{array}{ll}\text { Traits } \\
\end{array}$}} & \multicolumn{2}{|c|}{ Faba bean $(\%)$} & \multicolumn{2}{|c|}{ Fahl berseem (\%) } \\
\hline & & $\begin{array}{l}\text { Seed } N \\
\text { content }\end{array}$ & $\begin{array}{c}\text { Seed } \\
\text { protein } \\
\text { content }\end{array}$ & $\begin{array}{l}\text { Seed } N \\
\text { content }\end{array}$ & $\begin{array}{c}\text { Seed } \\
\text { protein } \\
\text { content }\end{array}$ \\
\hline \multicolumn{2}{|l|}{$60 \mathrm{~kg} \mathrm{~N}$ fed $^{-1}$} & 3.25 & 20.36 & 2.43 & 15.23 \\
\hline \multicolumn{2}{|l|}{$75 \mathrm{~kg} \mathrm{~N} \mathrm{fed}^{-1}$} & 3.91 & 24.48 & 2.64 & 16.52 \\
\hline \multicolumn{2}{|l|}{$90 \mathrm{~kg} \mathrm{~N}$ fed $^{-1}$} & 3.27 & 20.46 & 2.59 & 16.19 \\
\hline \multicolumn{2}{|c|}{ L.S.D. $0.05 \mathrm{~N}$ fertilizer levels } & 0.06 & 0.42 & 0.05 & 0.32 \\
\hline \multicolumn{2}{|c|}{$100 \%$ wheat $+20 \%$ faba bean or fahl berseem } & 3.28 & 20.54 & 2.52 & 15.76 \\
\hline \multicolumn{2}{|c|}{$100 \%$ wheat $+30 \%$ faba bean or fahl berseem } & 3.51 & 21.98 & 2.56 & 16.04 \\
\hline \multicolumn{2}{|c|}{$100 \%$ wheat $+40 \%$ faba bean or fahl berseem } & 3.62 & 22.65 & 2.58 & 16.13 \\
\hline \multicolumn{2}{|c|}{ L.S.D. 0.05 Intercropping systems } & $\mathbf{0 . 0 3}$ & $\mathbf{0 . 2 0}$ & 0.04 & 0.25 \\
\hline \multirow{3}{*}{$60 \mathrm{~kg} \mathrm{~N}$ fed $^{-1}$} & $100 \%$ wheat $+20 \%$ faba bean or fahl berseem & 3.03 & 18.96 & 2.41 & 15.06 \\
\hline & $100 \%$ wheat $+30 \%$ faba bean or fahl berseem & 3.33 & 20.81 & 2.45 & 15.33 \\
\hline & $100 \%$ wheat $+40 \%$ faba bean or fahl berseem & 3.55 & 22.20 & 2.44 & 15.29 \\
\hline \multirow{3}{*}{$75 \mathrm{~kg} \mathrm{~N}$ fed $^{-1}$} & $100 \%$ wheat $+20 \%$ faba bean or fahl berseem & 3.77 & 23.60 & 2.62 & 16.37 \\
\hline & $100 \%$ wheat $+30 \%$ faba bean or fahl berseem & 3.86 & 24.15 & 2.64 & 16.51 \\
\hline & $100 \%$ wheat $+40 \%$ faba bean or fahl berseem & 3.89 & 24.33 & 2.67 & 16.68 \\
\hline \multirow{3}{*}{$90 \mathrm{~kg} \mathrm{~N} \mathrm{fed}^{-1}$} & $100 \%$ wheat $+20 \%$ faba bean or fahl berseem & 3.05 & 19.06 & 2.54 & 15.87 \\
\hline & $100 \%$ wheat $+30 \%$ faba bean or fahl berseem & 3.35 & 20.98 & 2.62 & 16.37 \\
\hline & $100 \%$ wheat $+40 \%$ faba bean or fahl berseem & 3.42 & 21.40 & 2.61 & 16.33 \\
\hline \multicolumn{2}{|c|}{ L.S.D. 0.05 Interaction } & 0.05 & 0.36 & NS & NS \\
\hline \multicolumn{2}{|l|}{ Sole culture } & 3.91 & 37.76 & 2.64 & 16.52 \\
\hline
\end{tabular}

bean seeds.

\subsubsection{Intercropping patterns}

Seed $\mathrm{N}$ and protein contents of fahl berseem and faba bean were affected significantly by intercropping patterns in the combined analysis (Table 9). Intercropping pattern $100 \%$ wheat + $40 \%$ fahl berseem or faba bean increased $(P \leq 0.05)$ seed $\mathrm{N}$ and protein contents, meanwhile the lowest values of seed $\mathrm{N}$ and protein contents of fahl berseem and faba bean were obtained by intercropping pattern $100 \%$ wheat $+20 \%$ fahl berseem and $20 \%$ faba bean, respectively. These results were due to intercropping pattern $100 \%$ wheat $+40 \%$ fahl berseem or faba bean improved $\mathrm{N}, \mathrm{P}, \mathrm{K}$ and $\mathrm{O}$. $\mathrm{M}$. in rhizosphere of wheat roots (Table 2) which reflected positively on decreasing interspecific competition between the intercrops for basic growth resources. Similar results were observed by Sarunaite and Kadziuliene (2010) who found that the significantly higher crude protein concentration was observed in the total intercrops grain yields compared with the sole wheat yield.

\subsubsection{Interaction between $\mathbf{N}$ fertilizer levels and intercropping patterns}

Seed $\mathrm{N}$ and protein contents of faba bean were affected significantly by $\mathrm{N}$ fertilizer levels $\mathrm{X}$ intercropping patterns in the combined analysis, meanwhile seed $\mathrm{N}$ and protein contents of fahl berseem were not affected (Table 9). Intercropping pattern $100 \%$ wheat $+40 \%$ faba bean with the application of $75 \mathrm{~kg} \mathrm{~N}^{-1}$ had the highest seed $\mathrm{N}$ and protein contents, meanwhile the lowest values of grain $\mathrm{N}$ and protein contents were obtained by intercropping pattern $100 \%$ wheat $+20 \%$ faba bean that received either 60 or $90 \mathrm{~kg} \mathrm{~N}$ fed $^{-1}$.

\subsection{Competitive relationships}

\subsubsection{Land Equivalent ratio (LER)}

The total LER values were greater than one in all the studied treatments. The highest values were obtained by (1.25) under intercropping pattern $100 \%$ wheat $+20.0 \%$ barseem fahl that received $75 \mathrm{~kg} \mathrm{~N} \mathrm{fed} \mathrm{and} \mathrm{(1.33)} \mathrm{under}$ intercropping pattern $100 \%$ wheat $+20 \%$ faba bean that received $75 \mathrm{~kg} \mathrm{~N}^{-1}$. While, The lowest values were obtained by (1.04) under intercropping pattern $100 \%$ wheat+ $40.0 \%$ barseem fahl with the application of $90 \mathrm{~kg} \mathrm{~N}$ fed $^{-1}$ and (1.10) under intercropping pattern $100 \%$ wheat $+40 \%$ faba bean with the application of $90 \mathrm{~kg} \mathrm{~N} \mathrm{fed}{ }^{-1}$ (Fig. 1) and (Table10). 
Table (10): Effect of nitrogen fertilizer levels and intercropping faba bean or fahl barseem on LER,CR and average of net return (the combined analysis).

\begin{tabular}{|c|c|c|c|c|c|c|c|c|c|c|c|c|}
\hline \multirow{2}{*}{$\begin{array}{l}\text { Nitrogen } \\
\text { levels }\end{array}$} & \multirow{2}{*}{$\begin{array}{c}\text { Intercr } \\
\text { opping } \\
\text { treatme } \\
\text { nts }\end{array}$} & \multicolumn{3}{|c|}{ Intercropping Yields } & \multicolumn{3}{|c|}{ LER } & \multicolumn{2}{|c|}{ CR } & \multicolumn{3}{|c|}{$\begin{array}{c}\text { Economic evaluation } \\
\text { (L.E.) }\end{array}$} \\
\hline & & $\begin{array}{c}\text { Wheat } \\
\text { Ton fed }^{-1}\end{array}$ & $\begin{array}{c}\text { Faba } \\
\text { bean } \\
\text { kg/fed }\end{array}$ & $\begin{array}{c}\text { Fahl } \\
\text { berseem } \\
\text { kg/fed }\end{array}$ & $\mathbf{L}_{\mathbf{w}}$ & $\mathbf{L}_{\mathbf{b}}$ & Total & $\mathbf{C R}_{\mathrm{w}}$ & $\mathbf{C R}_{\mathrm{b}}$ & $\begin{array}{c}\text { Total } \\
\text { revenue }\end{array}$ & $\begin{array}{l}\text { Total } \\
\text { cost }\end{array}$ & $\begin{array}{c}\text { Net } \\
\text { return }\end{array}$ \\
\hline \multirow{6}{*}{$60 \mathrm{~kg} \mathrm{~N} \mathrm{fed}^{-1}$} & $\mathrm{~B}_{1}$ & 2.647 & 144.0 & - & 1.04 & 0.15 & 1.19 & 1.39 & 0.72 & 10282 & 7542 & 2740 \\
\hline & $\mathrm{B}_{2}$ & 2.632 & 178.5 & - & 1.04 & 0.19 & 1.22 & 1.64 & 0.61 & 10240 & 7572 & 2668 \\
\hline & $\mathrm{B}_{3}$ & 2.578 & 213.5 & - & 1.02 & 0.22 & 1.24 & 1.85 & 0.54 & 10282 & 7602 & 2680 \\
\hline & $\mathrm{B}_{4}$ & 2.498 & - & 43.0 & 0.99 & 0.11 & 1.09 & 1.80 & 0.56 & 9659 & 7542 & 2117 \\
\hline & $\mathrm{B}_{5}$ & 2.377 & - & 47.5 & 0.94 & 0.12 & 1.06 & 2.35 & 0.43 & 9440 & 7572 & 1868 \\
\hline & $\mathrm{B}_{6}$ & 2.237 & - & 53.0 & 0.88 & 0.13 & 1.01 & 2.74 & 0.37 & 9328 & 7602 & 1726 \\
\hline Average & & & & & & & & & & 9871 & 7572 & 2299 \\
\hline \multirow{6}{*}{$75 \mathrm{~kg} \mathrm{~N}$ fed $^{-1}$} & $\mathrm{~B}_{1}$ & 2.973 & 159.0 & - & 1.16 & 0.17 & 1.33 & 1.36 & 0.73 & 11358 & 7595 & 3763 \\
\hline & $\mathrm{B}_{2}$ & 2.795 & 211.5 & - & 1.10 & 0.22 & 1.32 & 1.50 & 0.67 & 11156 & 7625 & 3531 \\
\hline & $\mathrm{B}_{3}$ & 2.571 & 234.5 & - & 1.01 & 0.24 & 1.26 & 1.68 & 0.59 & 10623 & 7655 & 2968 \\
\hline & $\mathrm{B}_{4}$ & 2.849 & - & 53.0 & 1.12 & 0.13 & 1.25 & 1.72 & 0.58 & 11313 & 7595 & 3718 \\
\hline & $\mathrm{B}_{5}$ & 2.472 & - & 57.0 & 0.97 & 0.14 & 1.12 & 2.10 & 0.48 & 10404 & 7625 & 2779 \\
\hline & $\mathrm{B}_{6}$ & 2.357 & - & 60.0 & 0.93 & 0.15 & 1.08 & 2.48 & 0.40 & 10315 & 7655 & 2660 \\
\hline Average & & & & & & & & & & 10908 & 7625 & 3283 \\
\hline \multirow{6}{*}{$90 \mathrm{~kg} \mathrm{~N}$ fed $^{-1}$} & $\mathrm{~B}_{1}$ & 2.435 & 149.0 & - & 0.96 & 0.15 & 1.11 & 1.28 & 0.78 & 9770 & 7647 & 2123 \\
\hline & $\mathrm{B}_{2}$ & 2.321 & 194.0 & - & 0.92 & 0.20 & 1.12 & 1.37 & 0.73 & 9547 & 7677 & 1870 \\
\hline & $\mathrm{B}_{3}$ & 2.308 & 207.5 & - & 0.91 & 0.22 & 1.13 & 1.65 & 0.60 & 9564 & 7707 & 1857 \\
\hline & $\mathrm{B}_{4}$ & 2.463 & - & 53.0 & 0.97 & 0.13 & 1.10 & 1.49 & 0.67 & 10308 & 7647 & 2661 \\
\hline & $\mathrm{B}_{5}$ & 2.350 & - & 55.0 & 0.93 & 0.14 & 1.06 & 1.99 & 0.50 & 10058 & 7647 & 2411 \\
\hline & $\mathrm{B}_{6}$ & 2.265 & - & 59.0 & 089 & 0.15 & 1.04 & 2.37 & 0.42 & 10082 & 7677 & 2405 \\
\hline Average & & & & & & & & & & 9888 & 7667 & 2221 \\
\hline \multicolumn{2}{|l|}{ Solid wheat } & \multicolumn{3}{|c|}{2.536 ton $\mathrm{fed}^{-1}$} & - & - & 1 & - & - & 8937 & 7707 & 1230 \\
\hline \multicolumn{2}{|c|}{ Solid Faba bean } & \multicolumn{3}{|c|}{0.964 ton fed $^{-1}$} & - & - & 1 & - & - & 7432 & 6101 & 1331 \\
\hline \multicolumn{2}{|c|}{ Solid Fahl berseem } & 0.401 ton $\mathrm{f}$ & $\mathrm{ed}^{-1}$ & & - & - & 1 & - & - & 9015 & 6937 & 2078 \\
\hline \multicolumn{5}{|c|}{$L_{w}:$ Land equivalent ratio of wheat. } & \multicolumn{8}{|c|}{$\mathbf{L}_{\mathbf{b}}$ : Land equivalent ratio of faba bean or fahl berseem } \\
\hline \multicolumn{5}{|c|}{$\mathrm{CR}_{\mathrm{w}}$ : Competitive ratio of Wheat. } & \multicolumn{8}{|c|}{$\mathrm{CR}_{\mathrm{i}}$ : Competitive ratio of faba bean or fahl berseem } \\
\hline \multicolumn{2}{|c|}{$\begin{array}{l}B_{1: 100 \%} \text { wheat }+20 \% \\
\text { faba bean }\end{array}$} & & & \multicolumn{4}{|c|}{$B_{2:} 100 \%$ wheat $+30 \%$ faba bean } & \multicolumn{5}{|c|}{$B_{3:} 100 \%$ wheat $+40 \%$ faba bean } \\
\hline \multicolumn{2}{|c|}{$\begin{array}{l}\text { B }_{4:} \quad 100 \% \text { wheat }+ \\
20 \% \text { fahl berseem }\end{array}$} & \multicolumn{6}{|c|}{$\mathrm{B}_{5:} \mathbf{1 0 0 \%}$ wheat $+30 \%$ fahl barseem } & \multicolumn{5}{|c|}{$B_{6:} 100 \%$ wheat $+40 \%$ fahl berseem. } \\
\hline
\end{tabular}

Generally, these results reveal that intercropping pattern $100 \%$ wheat $+20 \%$ barseem fahl or $100 \%$ wheat $+20 \%$ faba bean interacted with $75 \mathrm{~kg} \mathrm{~N}$ fed $^{-1}$ to decrease inter or intra-specific competition between plants of the intercrops or plants of wheat, respectively, for available environmental conditions. In other words, the lowest of plant density of legume component increased inter-specific complementary interactions between the intercrops for basic growth.Resources and this effect was improved by increasing mineral $\mathrm{N}$ fertilizer level from 60 to $75 \mathrm{~kg} \mathrm{~N} \mathrm{fed}^{-1}$. These results are in accordance with those observed by Abdel-Wahab and El Manzlawy, (2016) who indicated that the highest LER (1.32) was obtained by intercropping faba bean with four rows of wheat with the application of $100 \mathrm{~kg} \mathrm{~N}$ fed $^{-1}$ under sandy soil conditions.

\subsubsection{Competitive ratio (CR)}

Data in Fig. (2) and Table (10) Show CR values that express the exact degree of competitive. $\mathrm{CRw}$ of wheat was higher than $\mathrm{CRb}$ of fahl barseem or faba bean in all treatments. Wheat crop was more competitive than fahl barseem or faba bean indicating the dominance of wheat on fahl barseem or faba bean. CRw of wheat was increased by increasing the plant density of legume component but the reverse was true for $\mathrm{CRb}$ of fahl barseem or faba bean. 


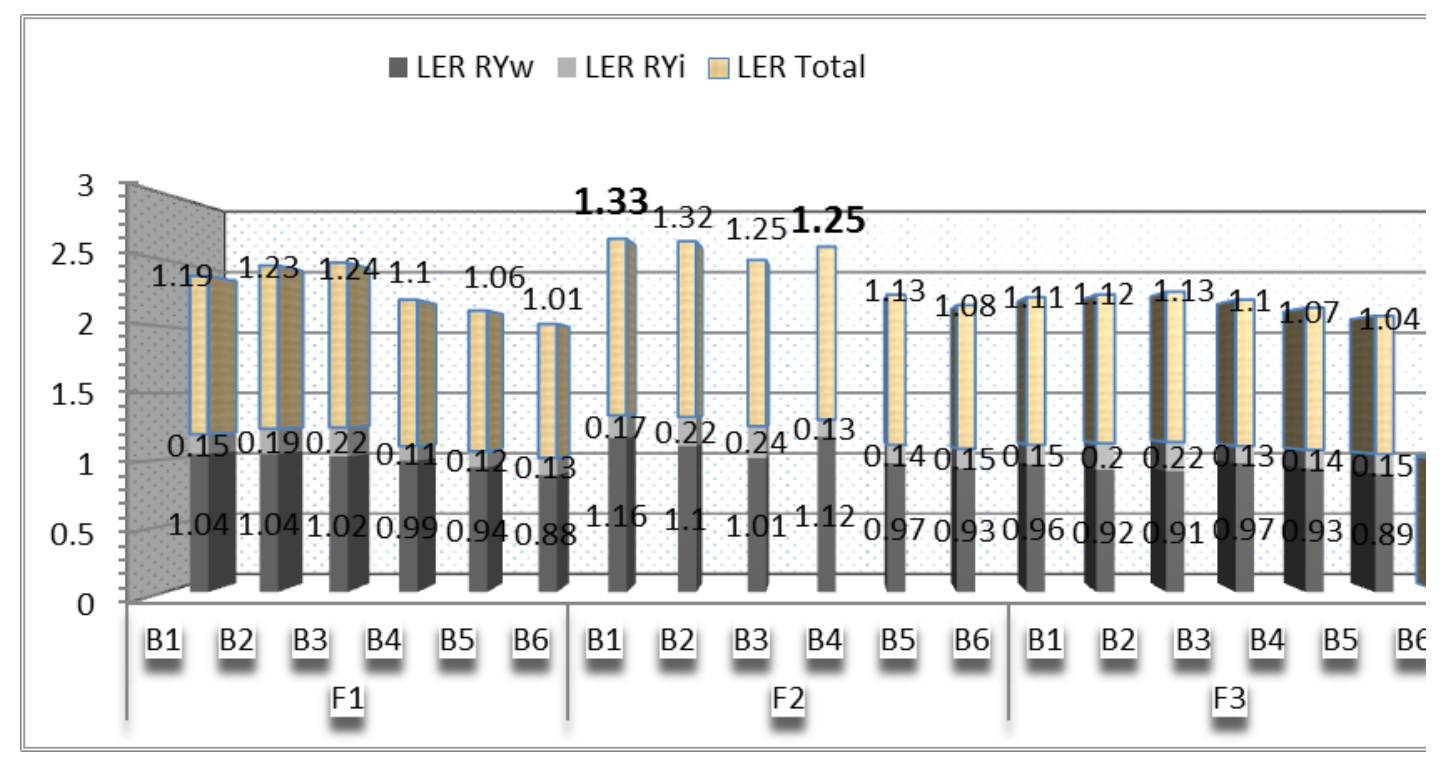

Fig. (1): Land equivalent ratio (LER) as affected by $\mathbf{N}$ fertilizer levels, intercropping patterns and their interaction, combined data across $2013 / 2014$ and 2014/2015.

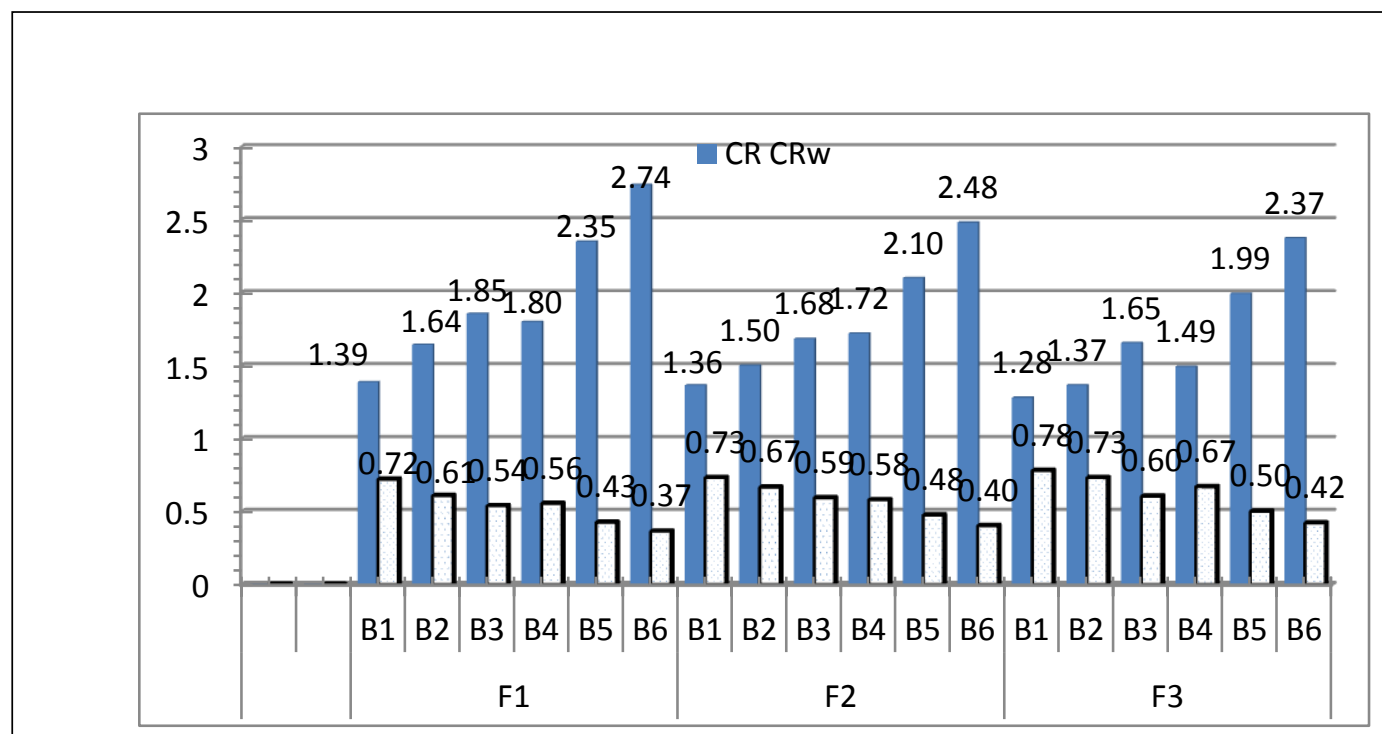

Fig. (2): Competitive ratio (CR) as affected by mineral $\mathrm{N}$ fertilizer levels, intercropping fahl barseem or faba bean and their interactions, combined data across 2013/2014 and 2014/2015.

\subsubsection{Financial return}

The financial returns of intercropped wheat as compared to sole wheat are shown in (Table 10). Intercropping fahl barseem or faba bean increased total and net returns compared to sole wheat. Net return of intercropped wheat varied from L.E. 1726 to $3783 \mathrm{fed}^{-1}$ compared to sole wheat (L.E. $1230 \mathrm{fed}^{-1}$ ). Clearly, application of $75 \mathrm{~kg} \mathrm{~N} \mathrm{fed}^{-1}$ achieved the highest net return of farmers compared to the other mineral $\mathrm{N}$ fertilizer levels. Accordingly, intercropping patterns $100 \%$ wheat $+20 \%$ faba bean and $100 \%$ wheat $+20 \%$ fahl barseem that received $75 \mathrm{~kg} \mathrm{~N} \mathrm{fed}^{-1}$ increased net return of farmers by L.E. 2553 and 2488 per fed, respectively, over those of sole wheat. These results are in accordance with those obtained by Agegnehu et al. (2006) who found that mixed intercropping faba bean in normal barley culture at a density not less than $37.5 \%$ of the sole faba bean gave better overall yield and income than sole culture of each crop species. Also, Mohammed Wafaa, 
(2014) showed that intercropping faba bean with wheat that received $285.6 \mathrm{~kg} / \mathrm{ha}$ gave higher net income compared to sole wheat

\section{Conclusion}

Our results demonstrated that intercropping legumes with wheat had significant effects on bacterial community diversity in the rhizosphere of wheat and helped to increase availability of soil $\mathrm{N}, \mathrm{P}, \mathrm{K}$ and $\mathrm{O}$. M. contents without excessive mineral $\mathrm{N}$ in the same season. Intercropping berseem or faba bean with wheat can be a practicable alternative to reduce the use of mineral $\mathrm{N}$ fertilizer per unit area by increasing inter-specific complementary interactions between the intercrops. intercropping patterns $100 \%$ wheat $+20 \%$ faba bean and $100 \%$ wheat $+20 \%$ fahl berseem that received $75 \mathrm{~kg} \mathrm{~N} \mathrm{fed}^{-1}$ increased net return of farmers by L.E. 2553 and 2488 per fed, respectively, over those of sole wheat.

\section{REFERENCES}

Abdel-moniem A. A., Ali F. S. and Hassan M. A. (1988). Studies on phosphate dissolving bacteria in rhizospher soil and rhizoplan of some vegetable plants. Minia J. Agric. Res. Dev.,(4): 1877-1898.

Abdel-Wahab T.I. and El Manzlawy Amal M. (2016). Yield and quality of intercropped wheat with faba bean under different wheat plant densities and slow - release nitrogen fertilizer rates in sandy soil. Amer. J. Exp. Agric., 11(6): 1 - 22.

Abedi T., Alemzadeh A. and Kazemeini S.A. (2011). Wheat yield and grain protein response to nitrogen amount and timing. Austr. J. Crop Sci., 5 (3): 330 - 336.

Abou-Keriasha M.A., Eisa Nadia M.A. and ElWakil N.H.M. (2013). Effects of intercropping faba bean on onion and wheat with or without inoculated bacteria on yields of the three crops. Egypt. J. Agron., 35 (2): 169 - 182.

Agegnehu G., Ghizaw A. and Sinebo W. (2006). Yield performance and land-use efficiency of barley and faba bean mixed cropping in Ethiopian high lands. Eur. J. Agron., 25:202-207.

Agricultural Statistics (2015). Winter crops. Agric. Sta. and Economic sector, Ministry of Agric. and land Reclamation, Egypt.

Allen O. N. (1959). Experiments in soil Bacteriology. $3^{\text {rd }}$ ed..Burgess publishing Co., Minneapolis, Minnesota, USA.
Al-Suhaibani N., El-Hendawy S. and Schmidhalter U. (2013). Influence of varied plant density on growth, yield and economic return of drip irrigated faba bean (Vicia faba L.). Turk. J. Field Crops, 18(2): 185 - 197.

Arshad M., Hussain N., Schmeiskyc H. and Rasheed M. (2016). Enhancing soil fertility through intercropping, inoculation and fertilizer. Pak. J. Sci. Industrial Res.,59(1):1-5.

A.O.A.C. (2000). Association of official agricultural chemists, official and tentative methods of analysis, $11^{\text {th }}$ ed. Washington, D.C., USA.

Bargaz A., Isaac M.E., Jensen E.S. and Carlsson G. (2015). Intercropping of faba bean with wheat under low water availability promotes faba bean nodulation and root growth in deeper soil layers. Proc. Environ. Sci., 29: 111 - 112.

Basma R. A. Rashwan, Ali A. M. A. and Shaima H. F. Abo Zaed. (2016). Effect of Organic and Bio-Fertilization as Partial Substitute for Mineral Nitrogen Fertilization on Wheat Plants. J. Soil Sci. and Agric. Eng., Mansoura Univ., 7 (5): 335 - 344.

Black C.A.M. (1965). Methods of Soil Analysis 'Part II A.S.A.Madison, Wiskinson., USA.

Bozorgi H.R., Azarpour E. and Moradi M. (2011). The effect of bio, mineral nitrogen fertilization and foliar zinc spraying on yield and components of faba bean. World Appl. Sci. J., 13 (6): 1409 - 1414.

Bulletin of Statistical Cost Production and Net Return (2015). Winter field crops and vegetables and fruit, agriculture statistics and economic sector Egyptian Agriculture and Land Reclamation, Part (1)

Campbell B.J., Polson S.W., Hanson T.E., Mack M.C. and Schuur E.A.G. (2010). The effect of nutrient deposition on bacterial communities in Arctictundra soil. Environ. Microbiol., 12: 1842 - 1854.

Chen C., Westcott M., Neill K., Wichman D. and Knox M. (2004). Row configuration and nitrogen application for barley - pea intercropping organic farming. Int $` 1 \mathrm{~J}$. pest Manage., 56 (2): 173 - 181.

Dahmardeh M.M., Ramroodi M. and Valizadeh J. (2010). Effect of plant density and cultivars on growth, yield and yield components of faba bean (Vicia faba L.). African J. Biotechnology 9 (50): 8643 8647. 
El Naggar S.M., Haggag M.E.A., Nofal Z.A. and Ramadan M.R. (1991). Effect of intercropping berseem on barley, and wheat. A. Growth and yield. Egypt. J. Appl. Sci., 6 (4): $92-112$.

Eskandari H. and A. Ghanbari (2010). Effect of different planting pattern of wheat (Triticum aestivum L.) and bean(vicia faba) on grain yield, dry matter production and weed biomass. Notulae Sci. Biol. 2: 111-115.

Eskandari H.O. (2011). Intercropping of wheat (Triticum aestivum 1.) and bean (Vicia faba) Effects of complementarity and competition of intercrop component in resource consumption on dry matter production and weed growth. Afr. J. Biotechno .10 (77): 17755-17762 Field Crops Res., 71: $17-29$.

Fan F., Zhang F. and Lu Y. (2011). Linking plant identity and interspecific competition to soil nitrogen cycling through ammonia oxidizer communities. Soil Biol. Biochem., 43: 46 - 54.

Gibson L., Jeremy S. and Stephen B. (2006). Intercropping winter cereal grains and red clover. Univ. Extension, Iowa State Univ.Available on file://C:/Users/hp/Downloads/PM2025\% 20(1). pdf .

Golabi M. and Lak S.H. (2005). Study of the effect of nitrogen application and plant density on quantitative and qualitative yield of broad bean (Vicia faba L.) in climatical conditions of Ahvaz. Proc. First National Sym. Pulse Crops, 20 - 21 Nov., Mashhad, Iran.

Gregorich E.G. Drury C.F. Baldock J.A. (2001). Changes in soil carbon under long-term maize in monoculture and legume-based rotation. Can., J. Soil Sci., 81: 21-31.

Gutierrez-Manero F.J., Ramos-Solano B., Probanza A., Mehouachi J.R., Tadeo F. and Talon M. (2001). The plant-growthpromoting rhizobacteria Bacillus pumilus and Bacillus licheniformis produce high amounts of physiologically active gibberellins. Physiol. Plant., 111 (2): 206 -211 .

Hagedorn F., Spinnler D. and Siegwolf R. (2003). Increased $\mathrm{N}$ deposition retards mineralization of old soil organic matter. Soil Biol. Biochem., 35: 1683 - 1692.

Hoskine J. K. (1934). The most probable numbers for evaluation of coliaerogenes test by fermentation tube method. Cited by porter, J. R. In: Bacterial chemistry and physiology, $2^{\text {nd }}$ ed., New York, London, John Wiley @ Sons, p.100

Jackson M.L. (1967). Soil Chemical Analysis Prentice. Hall of India Private Limited, 144 - 197, New Delhi, India.

Jian-Gang, L., Min-Chong S., Jin-Feng H., Ling L., Jun-Xia W. and Yuan-Hua D. (2016). Effect of different levels of nitrogen on rhizosphere bacterial community structure in intensive monoculture of greenhouse lettuce. Sci. Repts., 6: $1-9$.

Kandil A.A. and Sharief A.E. (2016). New Approach for Increasing Egyptian Clover Productivity in North Delta. STC Agric. Nat. Resources, 02 (05): $08-27$.

Khamooshi H., Mohammadian N., Saamdaliri M. and Foroughi Z. (2012). Study on effect of plant density and nitrogen on yield and yield components of Visia faba. L (Faba bean). J. Ornamental and Hort. Plants, 2 (3): 161 - 167.

Kumar V. and Narula N. (1999). Solubilization of inorganic phosphates and growth emergance of wheat as affected by Azotobacter chroococcum. Biol. Fertil. Soils, 28: $301-305$.

Lincoln T. and Edvardo Z. (2006). Assimilation of mineral nutrition. In: Plant Physiology ( $4^{\text {th }}$ ed.), Sinaur Associates Inc. Publish, Sunderland, PP. 705.

Marschner P., Yang C.H., Lieberei R. and Crowley D.E. (2001). Soil and plant specific effects on bacterial community composition in the rhizosphere. Soil Biol. Biochem., 33: 1437 - 1445.

Mead R. and Willey R.W. (1980). The concept of a "land equivalent ratio" and advantages in yields from intercropping. Exp. Agric., 16: 217 - 228.

Mohammed Wafaa Kh. (2014). Yield advantages of faba bean intercropped with wheat and different $\mathrm{N}$ fertilizer in reclaimed land. Egypt. Appl. Sci., 29(7B): $417-433$.

MSTATC (1980). A Micro computer program of design management and analysis of agronomic research experiments. Michigan State Univ., USA.

Murphy B.W. (2015). Impact of soil organic matter on soil properties- a review with emphasis on Australian soils. Soil Res., 53: $605-635$. 
Ndakidemi P. A., Dakora F. D., Nkonya E.M., Ringo D. and Mansoor H. (2006). Yield and economic benefits of common bean (Phaseolus vulgaris) and soybean (Glycine max) inoculation in northern Tanzania. Aust. J. Exper. Agric., 46:571577.

Piper C.S. (1950). Soil and Plant Analysis. Inter Science Publisher Inc., New York., USA.

Richards L.A. (1954). Diagnosis and Improvement of Saline and Alkaline Soils. U.S.D. A HandBook, No. 60.

Richardson A.E., Barea J.M., McNeill A.M. and Prigent-Combaret C. (2009). Acquisition of phosphorus and nitrogen in the rhizosphere and plant growth promotion by microorganisms. Plant and Soil, 321: $305-339$.

Sadasivam S. and Manickam A. (1997). Biochemical Methods. $2^{\text {nd }}$ edn. New age international (p) Ltd. Publisher, New Delhi,India, p: 5 - 207.

Sarunaite L. D. I. and Kadziuliene Z. (2010). Intercropping spring wheat with grain legume for increased production in an organic crop rotation. Žemdirbystè agric., 97(3): $51-58$.

Sharief A. E., El-Kalla S. E., Lielha A.A. and Mostafa H.E.M. (1998). Response of some wheat cultivars to nitrogen fertilizer levels and biological fertilization. J. Agric. Sci., Mansoura Univ., 23(12): 5807-5816.

Sheha A.M., Abdel-Wahab T.I. and AbdelWahab Sh.I.(2015). Maximizing Nitrogen and Land Use Efficiencies of Intercropped Wheat with Pea Under Different Pea
Sowing Dates. J. Plant Sci.,3(6):358-371.

Snedecor G.W. and Cochran W.G. (1989). "Statistical Methods". $8^{\text {th }}$ ed. Iowa State Univ. Press. Ames, Iowa, USA.

Song Y.N., Zhang F.S., Marschner P. (2007). Effect of intercropping on crop yield and chemical and microbiological properties in rhizosphere of wheat (Triticum aestivum L.), maize (Zea mays L.), and faba bean (Vicia faba L.). Biol. and Fert. Soils, 43: $565-574$.

Tosti G., Farneselli M., Benincasa P. and Guiducci M. (2016). Nitrogen Fertilization Strategies for Organic Wheat Production: Crop Yield and Nitrate Leaching. Agron. J., 108: 770 - 781.

Tripath, R. D., Serivastave G. P., Misra M. S. and Pandey, S. C. (1971). Protein content in some variations of legumes. The Allah Abad Farmer, 16: 291 - 294.

Vandermeer J. H. (1989). The ecology of intercropping. Cambridge Univ. Press, New York., USA.

Willey R.W. and Rao M.R. (1980). A competitive ratio for quantifying competition between intercrops. Exp. Agric., 16: 117 - 125.

Yildirim E. and Guvence I. (2005). Intercropping based on cauliflower: more productivity, profitable and highly sustainable. Europ. J. Agron., 22:1.

Zahran H. H. (1999). Rhizobium-legume Symbiosis and Nitrogen Fixation under severe Conditions and in an Arid Climate. Microbiology and Molecular Biology Revi. , 64(4): 968-989. 


\section{تأثير تحميل اثنين من المحاصيل البقولية و التسميد الآزوتي المعدني علي محصول القمح ونشاط الكائنات الحية الاقيقة في منطقة النتشار الجذور.}

*نادية محمد احمد عيسي - بسمة رشوان احمد رشوان* ـ شيماء حسن فتحي ابو زيد

قسم بحوث التكثيف المحصولي ـ معهد بحوث المحاصيل الحقليةـ مركز البحوث الزر اعية ــ مصر

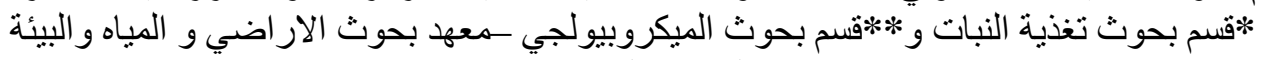

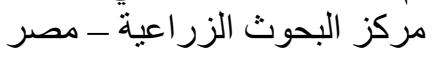

\section{ملخص بلموي}

أجريت تجربتين حقليتين في محطة البحوث الزراعية بملوي ( مصر الوسطي) خلال الموسمين (2014/2013 و

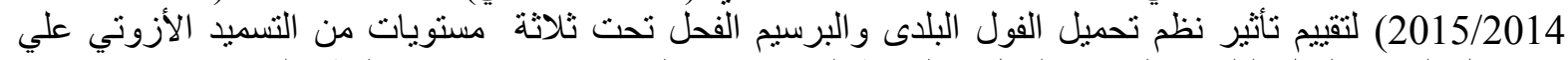

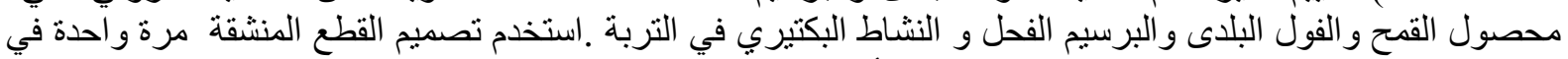

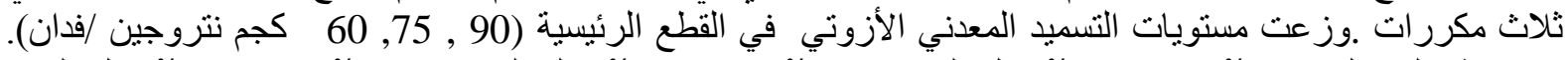

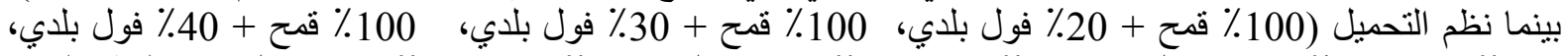

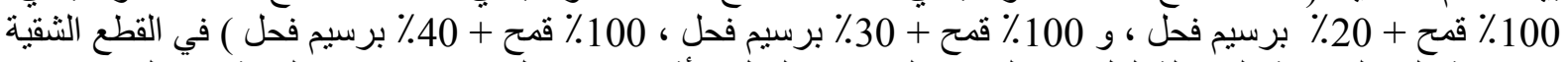

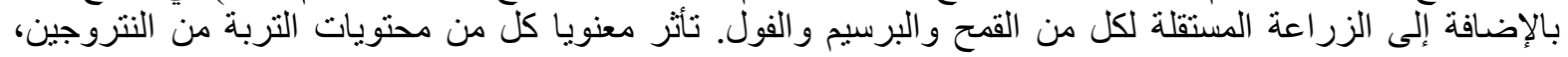

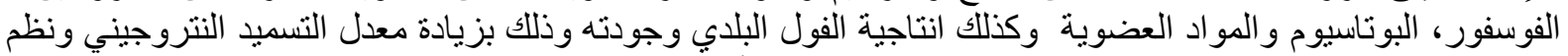

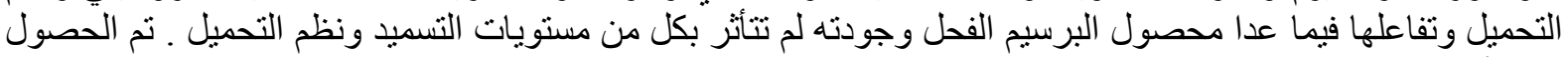

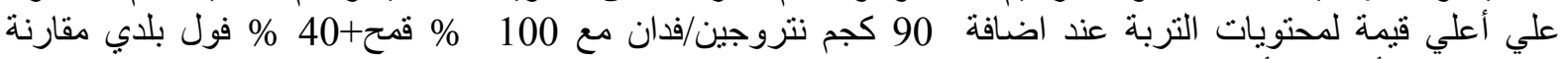

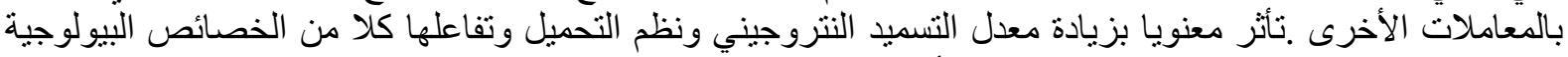

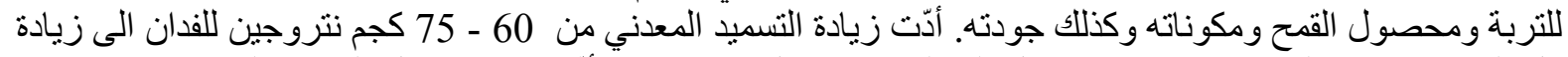

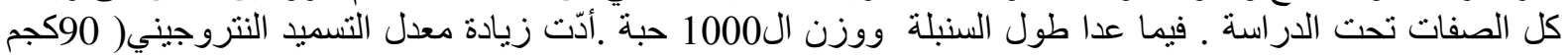

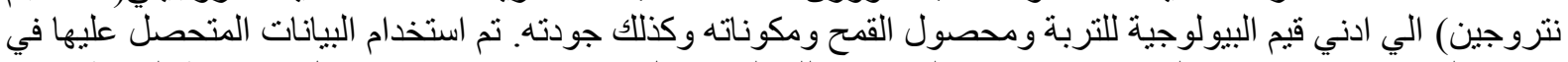

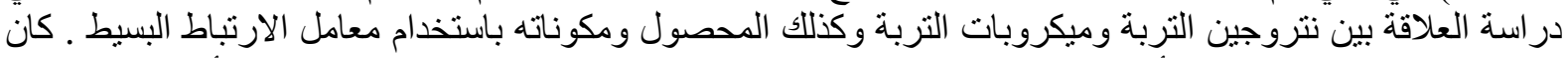

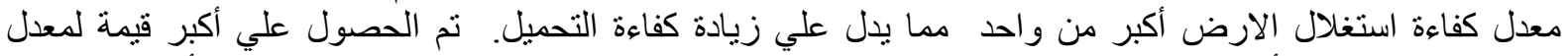

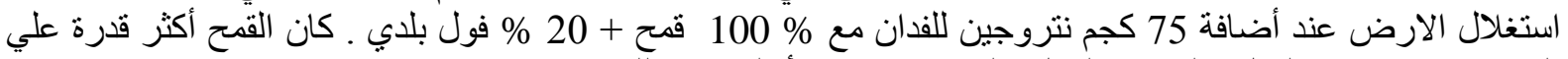

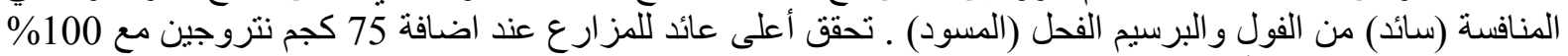

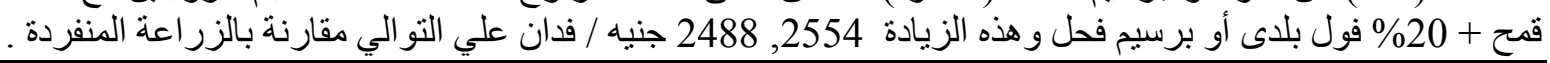

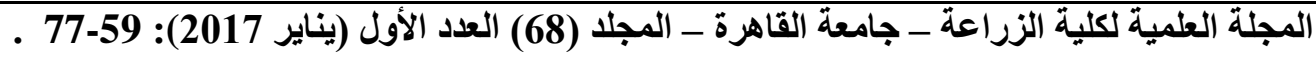

